\title{
NON-DISCRIMINATORY ROYALTIES FOR STANDARD ESSENTIAL PATENTS: SETTING THE BOUNDARIES
}

\author{
JULIA ÖSTERMAN*
}

\begin{abstract}
Technical standards often implicate patented technologies. This poses a risk of patent bold-up, whereby a standard essential patent ('SEP') holder opportunistically exploits its market power conferred by standardization and demands excessive and possibly differential royalties from implementers of the standard. Commitments to license on fair, reasonable, and non-discriminatory ( $\mathrm{F} / \mathrm{R} A N D$ ') terms imposed on SEP holders are intended to avoid that risk. Nevertheless, the practical implications of the nondiscrimination ('ND') prong of $F / R A N D$ bave become a subject of debate and litigation as a matter of contract and antitrust law. This paper seeks to answer the question: To what extent is a F/RAND-committed SEP holder legally allowed to charge differential royalties to different licensees for the patented technology from the U.S. and the EU perspectives?' It explores the meaning of the ND prong by examining IEEE, (= Institute of Electrical and Electronics Engineers) JEDEC, (= Joint Electron Device Engineering Council) and ETSI's (European Telecommunications Standards Institute) bylaws, inspecting U.S. and EU antitrust norms, analyzing case law of the U.S. and European courts, and reviewing legal and economic arguments in the academic literature. According to the dominant perception, SEP holders are obliged to license to similarly situated licensees on similar terms. Based on the interpretations in case law and literature, it is possible for a SEP bolder to charge differential royalties legally to licensees manufacturing dissimilar devices incorporating the technology, and even to licensees manufacturing similar devices when the needed transactions differ. Discrimination in royalties may also trigger antitrust liability when it is capable of harming competition, although the threshold is significantly lower in EU law than in U.S. law.
\end{abstract}

\section{INTRODUCTION}

Nowadays, technological devices are an integral part of everyday life. People connect via smartphones that operate over $3 \mathrm{G} / 4 \mathrm{G}$ networks and computers that operate over Wi-Fi. In order to function, these devices must communicate with each other, which often means compliance with technical standards. Due to the fast evolution of information and communications technology ('ICT') and the need for interoperability between devices, standards are more important than ever. Problematically, these standards may implicate hundreds of patents covering the technology and implementers of a standard may need to negotiate licenses to employ the patented

\footnotetext{
* LL.M graduate in European Business Law from Lund University in 2018. The article builds on the author's master thesis carried out at Lund University in 2018. It scrutinizes to what extent a standard essential patent holder who has committed to license on fair, reasonable, and non-discriminatory terms is allowed to charge differential royalties for the patented technology from the U.S. and the EU perspectives by examining IEEE, JEDEC, and ETSI's bylaws, inspecting U.S. and EU antitrust norms, analyzing case law of the U.S. and European courts, and reviewing legal and economic arguments in the academic literature. The author can be contacted via email: julia.osterman@gmail.com.
} 
technology. There is a risk of patent hold-up, whereby a standard essential patent ('SEP') holder opportunistically exploits its market power conferred by the inclusion of its patented technology into a standard and demands excessive royalties from implementers. SEP holders may be able to behave opportunistically and demand differential royalty rates across implementers as a result of different bargaining outcomes or for the reason that the implementer is a competitor.

In order to ensure follow-on innovation, SEP holders' freedom to license is limited. Limitations may flow from contractual obligations imposed by standard setting organizations ('SSOs') and/or from antitrust law. ${ }^{1}$ The purpose of commitments to license on fair, reasonable, and non-discriminatory ( $\mathrm{F} / \mathrm{RAND}^{2}$ ) terms imposed by SSOs is to both grant implementers access to the patented technology and reward the SEP holder for the contribution to the standard. Fair amount of research efforts has focused on the concept of 'reasonable' terms in the context of F/RAND licensing. However, the 'non-discriminatory' ('ND') prong of F/RAND has received far less attention from the courts and commentators although it has become a subject of debate and litigation. It is a problematic component to define. For example, is an identical royalty rate charged to all licensees based on profits of end-products incorporating the technology non-discriminatory? Then the royalty rate may be the same, but the actual royalty payments differ depending on the value of the endproducts. There seems to be consensus that similarly situated licensees should license on similar terms. However, the meanings of similarly situated licensees and similar license terms are not straightforward.

This paper aims to answer the question: 'To what extent is a F/RANDcommitted SEP holder legally allowed to charge differential royalties to different licensees for the patented technology from the U.S. and the European Union ('EU') perspectives?' It seeks to explore the meaning of the ND prong of F/RAND in the standard setting context and to discover its practical implications for SEP licensing practices in two important jurisdictions: the U.S. and the EU. Methodologically this paper examines SSOs' bylaws, inspects U.S. and EU antitrust norms, analyzes case law of the U.S. and European courts, and reviews legal and economic arguments in the academic literature. The research kicks off in the second chapter with a brief overview of patents generally and the limited freedom to license patented technology in the standard setting context. The third chapter initiates the profound analysis of the ND prong and looks into SSOs' bylaws, concentrating on three international SSOs (standard setting organizations) that are of great economic importance and subjects of litigation today: IEEE, JEDEC and ETSI. In the fourth chapter, the attitudes of U.S. and EU competition laws towards differential pricing and patentees' licensing practices are scrutinized. The fifth chapter analyses the case law development in the U.S. and the EU, which provides some ideas on the definition and implications of the ND prong. Finally, the sixth chapter proposes a framework for answering the question whether a F/RAND-committed SEP holder may set differential royalties to different

\footnotetext{
${ }^{1}$ For the purposes of this paper, 'antitrust' law and 'competition' law are used synonymously. ${ }^{2}$ For the purposes of this paper, 'F/RAND' refers to the concepts of 'FRAND' and 'RAND.' However, the concepts of FRAND and RAND are often used synonymously. See, for instance, Apple $v$ Motorola (ND Ill 2012) at 911-912; Microsoft v Motorola, (9th Cir 2012), at 877.
} 
licensees lawfully and to what extent. The focus lies on the prevalent interpretation that the ND prong imposes an obligation to license to similarly situated licensees on similar terms. The chapter distinguishes between two scenarios: first, when the licensees' devices incorporating the patented technology are dissimilar; and second, when the devices are similar.

This paper concludes that based on the examined interpretations, licensees manufacturing dissimilar devices are not similarly situated, and thus a F/RANDcommitted SEP holder is legally allowed to charge differential royalties at least to those licensees provided that the value contributed by the patented technology to the particular devices is apportioned convincingly. Licensees manufacturing similar devices are not inevitably similarly situated either, as factors relating the nature of the licenses may change the degree of similarity of the licensees' situations. Furthermore, it appears that F/RAND royalties may legitimately vary even across similarly situated licensees according to different licensing arrangements so long as the same menu of terms is available for all licensees. In addition, antitrust liability may be triggered in both U.S. and EU law when the practice of charging discriminatory royalties may harm competition, although the threshold is clearly lower in EU law.

\section{SEP LICENSING AND THE LIMITS TO THE FEEEDOM TO LICENSE}

Before looking into the ND prong of F/RAND and the question whether SEP holders have a right to set differential royalties, this chapter provides a brief overview of patents and how and why the freedom to license patented technology is limited in the standard setting context. The first section examines the patent regime, the rights it bestows, its economic rationale in the society, and some issues faced by it today. SSOs and the purpose of standard setting is discussed in the second section, as well as the risk of patent hold-up, and F/RAND commitments imposed by SSOs. The third section examines the intersection of the relevant legal regimes in relation to patent licensing practices, namely patent law, contract law, and antitrust law.

\subsection{UNDERSTANDING THE CONTEXT OF PATENTS AND LICENSING}

Incentives to discover and commercialize technologies are crucial in today's society where innovation drives economic growth. ${ }^{3}$ That is exactly what the patent regime seeks to provide: an incentive to invent technical solutions. ${ }^{4}$ In order to survive in the rapidly changing technology markets, companies must be able to protect their inventions. ${ }^{5}$ A patent remedies free-rider problems by the grant of a right to exclude

\footnotetext{
${ }^{3}$ Alan Devlin, Antitrust and Patent Law (Lars Kjølbye ed, OUP 2016) 63.

4 ibid; Daniel G Swanson and William J Baumol, 'Reasonable and Nondiscriminatory (RAND) Royalties, Standards Selection, and Control of Market Power' (2005) 73 Antitrust LJ 1, 2; Yann Ménière, 'Fair, Reasonable and Non-Discriminatory (FRAND) Licensing Terms, Research Analysis of a Controversial Concept' [2015] JRC science and policy report, 10; Alison Jones and Brenda Sufrin, EU Competition Law: Text, Cases, and Materials (6th edn, OUP 2016) 826-827.

${ }^{5}$ Donald Rimai, Patent Engineering: A Guide to Building a Valuable Patent Portfolio and Controlling the Marketplace (Wiley-Scrivener, 2016) 20.
} 
others from practising the invention. ${ }^{6}$ Without patents, companies might not invest capital and contribute to technological research and development ('R\&D') due to the possibility of appropriation. It is a trade-off: the government grants the patentee an exclusionary right in exchange for revealing the invention to the public. ${ }^{7}$

Patents are traditionally creatures of national law. The U.S. has a federal patent system. A U.S. patent grants a right to exclude others from making, using, selling, offering to sell, or importing the patented invention for twenty years from the filing date. ${ }^{8}$ It is available for inventions that are novel, non-obvious, and useful. ${ }^{9}$ In Europe, there is no unified patent regime. However, the European Patent Convention established the European Patent Organisation ('EPO') in 1977 of which all the $28 \mathrm{EU}$ member states and 10 other European states are members. It did not create a panEuropean patent but a centralized prosecution process. Furthermore, all EU member states except Croatia and Spain have agreed to create and recognize unitary patent protection, which is expected to become operational during the course of $2018,{ }^{10}$ and a Unified Patent Court, which is awaiting ratification. Analogously to a U.S. patent, European patents are available for inventions that are novel, involve an inventive step, and are susceptible of industrial application. ${ }^{11}$ However, unlike under U.S. law, schemes, rules and methods for doing business and programs for computers are excluded from European patentability. ${ }^{12}$

The potential revenue that may accrue from patents motivate companies to invest in R\&D. ${ }^{13}$ Patents can be commercialized through licensing, which refers to an act where the licensor transfers the licensee the right to make, sell and use products, processes or services embodying the technology for commercial use usually in exchange for remuneration, typically royalties. ${ }^{14}$ Licensing benefits both the licensor and the licensee, as well as the society as a whole as it stimulates further technological development. ${ }^{15}$ Nevertheless, there is a large variety of licensing practices, and the (typically bilaterally negotiated) license terms and royalty rates in particular may give rise to conflicts. Royalties are often based on the value of the patented technology relative to its next-best alternative. ${ }^{16}$ Many factors may be taken into account, such as the size and value of the potential licensees' patent portfolios and the possibility of cross-licensing. ${ }^{17}$

\footnotetext{
${ }^{6}$ Swanson and Baumol (n 4) 2; Devlin (n 3) 63; Jones and Sufrin (n 4) 830.

${ }^{7}$ Rimai (n 5) 22.

835 USC, JS 154, 271(a).

9 ibid SS 101-103.

${ }^{10}$ EPO, 'When will the Unitary Patent system start?' (18 September 2017)

<https://www.epo.org/law-practice/unitary/unitary-patent/start.html> accessed 15 June 2018.

${ }^{11}$ European Patent Convention, Art 52(1).

12 ibid Art 52(2)(c).

13 Swanson and Baumol (n 4) 2; Ménière (n 4) 10; Jones and Sufrin (n 4) 826-827.

${ }^{14}$ WIPO and ITC, Exchanging V alue, Negotiating Technology Licensing Agreements: A Training Manual (WIPO, 2005) 18.

15 ibid 13.

${ }^{16}$ Richard J Gilbert, 'Deal or No Deal? Licensing Negotiations in Standard-Setting Organizations' (2011) 77 Antitrust LJ 855, 860.

17 Anne Layne-Farrar and Paul Stuart, 'Abusive Discrimination' in Enrique Francisco González-Díaz and Robert Snelders (eds), EU Competition Law Volume V, Abuse of Dominance Under Art 102 TFEU (Claeys \& Casteels, 2013) 38.
} 
The patent regime has not progressed at the same rate as the patented invention. The world of technology changed drastically in the 1970s as consumers began to embrace digital technologies. ${ }^{18}$ The first home computer was introduced in 1977 along with video games, and companies such as Apple, Microsoft and Dell took the lead in the new consumer electronics market a few years later with simple and affordable computers. ${ }^{19}$ Then came the Internet, and the technology markets begun developing incredibly fast. ${ }^{20}$ Whereas a patent was initially designed to cover mechanical invention, a great number of new technologies are steered by microelectronics and computer software, and multiple technologies are often combined to create a consumer product. ${ }^{21}$ Thousands of patents may read on one single device. Today, the patent regime is inadequate to address all the issues related to new technology and industry structure. ${ }^{22}$ Broad exclusionary rights may both promote and impede technological progress depending on the industry. ${ }^{23}$ The great mass of patents (the so-called 'patent thicket') deters commercialization of technology when they are overlapping and laying claim to the same technologies. ${ }^{24}$ Furthermore, patents are not only defensive tools to protect inventions against appropriation, but also strategic weapons against rivals. ${ }^{25}$ As industry relies on self-help measures, the antitrust regime has become more and more relevant. ${ }^{26}$ Moreover, due to the patent regime's partial malfunction, companies avoid patent wars by joining together through, inter alia, patent pools and cross-licensing agreements. $^{27}$

\subsection{AVOIDING THE RISK OF PATENT HOLD-UP: F/RAND TERMS IN STANDARD SETTINGS}

SSOs are private organizations that develop, promulgate or otherwise maintain standards that aim to meet the technical objectives of a particular industry. ${ }^{28}$ They produce 'agreements containing technical specifications or other criteria' and promote economic efficiency by facilitating interoperability of devices. ${ }^{29}$ They provide protocols for the creation of interoperable devices through collaborative process by using common architectures made of a set of technologies. ${ }^{30}$ One of the reasons for forming SSOs is the same as for forming patent pools and cross-licensing agreements: attainment of clearing positions. ${ }^{31}$ Standards are issued by various SSOs, including

\footnotetext{
18 Rimai (n 5) 19.

19 ibid.

20 ibid 19-20.

${ }^{21}$ Devlin (n 3) 5-6, 66.

22 ibid 66.

23 ibid 9.

24 ibid 6.

25 ibid 60 .

26 ibid.

27 ibid.

28 J Gregory Sidak, 'The Meaning of FRAND, Part I: Royalties' (2013) 9(4) JCL\&E 931, 946, 948.

${ }^{29}$ US DOJ and US Patent \& Trademark Office, Policy Statement on Remedies for StandardsEssential Patents Subject to Voluntary F/RAND Commitments (Jan 8, 2013), 2-3.

${ }^{30}$ Joanna Tsai and Joshua D Wright, 'Standard Setting, Intellectual Property Rights, and the Role of Antitrust in Regulating Incomplete Contracts' (2015) 80(1) Antitrust LJ 157, 159; Devlin (n 3) 6, 35.

${ }^{31}$ Devlin (n 3) 6.
} 

IEEE, JEDEC, and ETSI. They are important in the new economy, particularly in ICT industries, ${ }^{32}$ as they provide industries with great benefits: ${ }^{33}$ they can reduce transaction costs, increase competition, and improve the value of consumer products especially through realization of network effects. ${ }^{34}$

Technical standards promulgated by SSOs often implicate patented technologies, and therefore implementers may need to negotiate licenses. The risk of abuse of standardisation is an important legal and economic concern. One of the recognized dangers with standardisation is that a patentee may 'hold-up' industry once an SSO chooses the patented technology into a standard and industry sinks capital into implementing it, although the hold-up theory lacks empirical evidence. ${ }^{35} \mathrm{~A}$ patent holdup situation may arise in expost ${ }^{36}$ negotiations between a patentee and an implementer when the patentee enjoys increased bargaining power than $e x$ ante $^{37}$ as the standard has reduced competitive alternative technologies. ${ }^{38} \mathrm{~A}$ Patentee may induce an SSO to adopt its technology into a standard but conceal its relevant patents from the SSO and later assert those patents against implementers (the so-called 'patent ambush'), or it may disclose them but without intention to license them on F/RAND terms and then use them to hold-up industry. ${ }^{39}$ In the latter situation, a SEP holder opportunistically exploits the incremental market power conferred by the inclusion of its technology into a standard and charges higher royalties to implementers than it would have charged ex ante along with a threat of assertion. ${ }^{40}$ A SEP holder may be able to do so when industry is locked into a standardized technology and implementers can no longer choose possible alternative technologies for their devices cheaply in order to avoid infringement. ${ }^{41}$ A SEP holder essentially seeks to capitalize implementers' sunk investment in devices that infringe the patent. Nevertheless, SEPs may be asserted not only to acquire royalties but also to exclude competitors from the market, as happened in the smartphone wars as of year $2009 .^{42}$

In order to avoid the risk of patent hold-up, it is common for SSOs like IEEE, JEDEC, and ETSI to require their members to disclose patents that may be essential to implementation of a standard and to agree to offer to negotiate a license on

\footnotetext{
32 Ménière (n 4) 9; Chryssoula Pentheroudakis and Justus A Baron, 'Licensing Terms of Standard Essential Patents, A Comprehensive Analysis of Cases' [2017] JRC science and policy report, 17. 33 US DOJ and US Patent \& Trademark Office, Policy Statement on Remedies for StandardsEssential Patents Subject to Voluntary F/RAND Commitments (Jan 8, 2013) 2; Tsai and Wright (n 30) 159; Devlin (n 3) 166.

34 Mario Mariniello, 'Fair, Reasonable, and Non-Discriminatory (FRAND) Terms: a Challenge for Competition Authorities' (2011) 7(3) JCL\&E 523, 523-524; Tsai and Wright (n 30) 159-160.

35 Ménière (n 4) 15; Pentheroudakis and Baron (n 32) 27.

${ }^{36}$ For the purposes of this paper, 'ex post' refers to the time after the SSO has chosen the patentee's technology into the standard.

${ }^{37}$ For the purposes of this paper, 'ex ante' refers to the time before the SSO has chosen the patentee's technology into the standard.

38 Pentheroudakis and Baron (n 32) 24-25.

${ }^{39}$ Devlin (n 3) 166; Pentheroudakis and Baron (n 32) 25-26.

${ }^{40}$ Dennis W Carlton and Allan L Shampine, 'An Economic Interpretation of FRAND' (2013) 9(3)

JCL\&E 531, 535; Ménière (n 4) 14-15; Devlin (n 3) 166; Pentheroudakis and Baron (n 32) 24-25.

${ }_{41}$ Carlton and Shampine (n 40) 535; Ménière (n 4) 14-15; Devlin (n 3) 166; Pentheroudakis and Baron (n 32) 24-25.

42 Devlin (n 3) 303-305.
} 
F/RAND terms. ${ }^{43}$ This information may affect SSOs' decisions to include a particular technology into a standard, in addition to the quality of the engineering. Although SSOs have been fairly silent about the reasons behind F/RAND terms, commentators have maintained that F/RAND terms seek to strike a balance between the interests of patentees and those of standard implementers. While F/RAND terms aim to make SEPs available to all implementers, no matter the implementer's position in the market, they should also allow SEP holders to extract rent deriving from the advantages of their technology over the next-best alternatives. ${ }^{44}$ In order to ensure incentives to innovate and to participate in standard setting, SEP holders must be able to recover their upfront R\&D investment. ${ }^{45}$ In other words, F/ RAND commitments operate as a safeguard against patent hold-up as well as patent hold-out (referring to implementers intentionally using patented technology essential to a standard without a license) ${ }^{46}$, and to foster standardization and the resulting benefits. SSOs can thus be conceptualized as sort of joint ventures and F/RAND commitments as ancillary restraints that are essential for the joint ventures' success. ${ }^{47}$

\subsection{INTERSECTION OF LEGAL REGIMES AS LIMITS TO THE FREEDOM TO LICENSE}

SEP licensing practices may be scrutinized through the lens of different applicable legal regimes such as patent law, antitrust law, and contract law. The three legal regimes interact with each other closely. F/RAND commitments limit SEP holders' right to exclude as a means to, inter alia, prevent the risk of patent hold-up, and those limitations may be enforced through contract law and/or antitrust law. The tension between antitrust and patent regimes flow from the fact that whereas patents bestow monopoly power legally, antitrust law seeks to proscribe it. ${ }^{48}$ Nevertheless, the U.S. and EU competition authorities consider antitrust and patent regimes to share the same objective: the promotion of innovation and consumer welfare, that is to say, high quality products and low prices. ${ }^{49}$ Patents remedy appropriation concerns and competitive markets lead to economic efficiency. The two bodies of law are, at least in theory, complementary. ${ }^{50}$ Regardless of the common objective, the rules may collide and antitrust law may override.

Antitrust law is a tool to limit the freedom of contract for the sake of competitive markets. Policy objectives such as economic freedom and fairness may be relevant too

\footnotetext{
${ }^{43}$ Mariniello (n 34) 524; Tsai and Wright (n 30) 171; Pentheroudakis and Baron (n 32) 28, 33.

44 US DOJ and US Patent \& Trademark Office, Policy Statement on Remedies for Standards-

Essential Patents Subject to Voluntary F/RAND Commitments (Jan 8, 2013) 5; Mariniello (n 34) 524;

Ménière (n 4) 7; Pentheroudakis and Baron (n 32) 11.

45 Mariniello (n 34) 524; Ménière (n 4) 7; Pentheroudakis and Baron (n 32) 21-23.

46 Ménière (n 4) 15; Pentheroudakis and Baron (n 32) 26.

${ }^{47}$ Sidak, 'The Meaning of FRAND, Part I: Royalties' (n 28) 951.

${ }^{48}$ See, for instance, United States v Westinghouse Elec Corp, (9th Cir 1981) at 646.

${ }^{49}$ Commission Communication, Guidelines on the application of Article 101 of the Treaty on the Functioning of the European Union to technology transfer agreements [2014] OJ C 89/03, para 7; US DOJ and FTC, Antitrust Enforcement and Intellectual Property Rights: Promoting Innovation and Competition (2007), 1.

50 Atari Games v Nintendo of Am, (Fed Cir 1990), at 1576.
} 
in addition to economic efficiency. ${ }^{51}$ The analysis of a company's conduct and its effects begins with examining the characteristics of the industry and the market in order to delimit the area of competition that restricts the company's ability to act independently. The market is defined by ascertaining the price elasticity of demand that the product faces at the competitive price level. However, defining the market is problematic with regards to SEPs. ${ }^{52}$ Many issues may affect the analysis, such as the existence of competing standards or complements. ${ }^{53}$ The prediction and prevention of anti-competitive consequences of conduct is not straightforward in a dynamic industry such as ICT. As exclusionary rights may both promote and impede R\&D, patent related conduct is subject to special antitrust treatment. Special treatment applies to SSOs and SEP holders too. Standard setting is essentially collaboration between rivals and therefore SSOs may pose a threat of horizontal collusion such as price fixing, which is prohibited in both U.S. and EU law. ${ }^{54}$ Nonetheless, standard setting is praised for producing positive economic effects. ${ }^{55}$ SSOs must take antitrust limitations into account. SEP holders must also be aware of antitrust limitations, as for instance engaging in patent hold-up may qualify as abuse of market power derived from the essentiality of a standard. However, Makan Delrahim, Assistant Attorney General for the Antitrust Division at the U.S. Department of Justice ('DOJ'), stated in March 2018 that hold-up is fundamentally not an antitrust problem, and therefore antitrust law should not be used as a tool to police FRAND commitments that patent-holders make to standard setting organizations. ${ }^{56} \mathrm{He}$ emphasized that antitrust enforcement requires empirical evidence, which patent hold-up theories lack. ${ }^{57}$ The U.S. enforcement agencies and courts are clearly less inclined to interfere in patent hold-up than those of the EU. Assistant Attorney General Delrahim added further that SSOs should ensure incentives to innovate and thus concentrate not only on the risk of hold-up by patentees but also on hold-out by implementers which 'poses a more serious threat to innovation. ${ }^{58}$

SEP holders' conduct may also be analysed through contract law as licensing practices may amount to a breach of a contractual obligation flowing from a F/RAND commitment. A contractual prohibition against price discrimination differs from a

\footnotetext{
51 Jones and Sufrin (n 4) 26-28.

52 Devlin (n 3) 307-308.

53 ibid 309; Anne Layne-Farrar, 'Nondiscriminatory Pricing: Is Standard Setting Different?' (2010) 6(4) JCL\&E 811, 819.

54 US DOJ and FTC, Antitrust Enforcement and Intellectual Property Rights: Promoting Innovation and Competition (2007), 37; Commission Communication, Guidelines on the applicability of Article 101 of the Treaty on the Functioning of the European Union to horizontal co-operation agreements [2011] OJ C 11/01, SS 273-274.

${ }^{55}$ US DOJ and FTC, Antitrust Enforcement and Intellectual Property Rights: Promoting Innovation and Competition (2007), 33; Commission Communication, Guidelines on the applicability of Article 101 of the Treaty on the Functioning of the European Union to horizontal co-operation agreements [2011] OJ C 11/01, § 263.

${ }^{56}$ US DOJ, Assistant Attorney General Makan Delrahim, 'The 'New Madison’ Approach to Antitrust and Intellectual Property Law' (Philadelphia, 16 March 2018)

$<$ https://www.justice.gov/opa/speech/assistant-attorney-general-makan-delrahim-delivers-keynoteaddress-university> accessed 15 June 2018.

57 ibid.

58 ibid.
} 

statutory antitrust prohibition at least in three ways ${ }^{59}$ First, the scope of the prohibition may differ, as parties to a contract are free to define the terms and the obligations imposed by them, whereas an antitrust prohibition is defined by the authorities. Second, the required evidence differs for establishing a breach of contract as opposed to a violation of antitrust law, as evidence of a valid contract and a breach of a contractual duty are required for the former. Moreover, standings to bring a claim are different. Lastly, the remedies for a breach of contract differ from those for an antitrust violation.

\section{THE ND PRONG IN SSOS' BYLAWS: DEFINING THE SCOPE OF THE PROTECTION}

Before answering the question whether F/RAND-committed SEP holders have a right to set differential royalties to different licensees, the definition of the ND prong of F/RAND needs to be analysed. The scrutiny to ascertain what is meant by nondiscriminatory terms or royalties for F/RAND purposes logically begins with SSOs' bylaws as F/RAND commitments are essentially agreements between patentees and SSOs. This chapter examines SSOs' policies on the ND prong. Clearly, the ND prong provides an umbrella of protection for implementers against strategic licensing conduct by SEP holders - it allows implementers to benefit from license terms negotiated by previous licensees. ${ }^{60}$ Nevertheless, the question is: to what extent can implementers rely on those terms?

The first section examines F/RAND commitments as contractual obligations and highlights the importance of identifying the intention behind SSOs' bylaws in the act of defining the ND prong of F/RAND. The second section reviews SSOs' bylaws regarding SEP licensing rules, focusing on three SSOs: international SSO IEEE, which has published standards in industries such as electrical engineering, computer science, and electronics; international SSO JEDEC in the microelectronics industry; and European SSO ETSI in the telecommunications industry. The section analyses how the prohibition of discrimination is expressed in the SSOs' policy documents, and whether they seem to allow SEP holders to set differential royalties.

\subsection{F/RAND COMMITMENTS AS CONTRACTUAL OBLIGATIONS}

In the context of standard setting, F/RAND commitments are essentially voluntary undertakings taken by participants to a standard in accordance with SSOs' policies by virtue of participation in the standard setting process or through a letter of assurance. ${ }^{61}$

\footnotetext{
${ }^{59} \mathrm{~J}$ Gregory Sidak, 'Fair and Unfair Discrimination in Royalties for Standard-Essential Patents Encumbered by a FRAND or RAND Commitment' (2017) 2 The Criterion Journal on Innovation $301,326$.

${ }^{60}$ Gilbert (n 16) 860.

${ }^{61}$ Roger G Brooks and Damien Geradin, 'Interpreting and Enforcing the Voluntary FRAND Commitment' [2011] Cravath, Swaine and Moore LLP

$<$ https://www.cravath.com/files/Uploads/Documents/Publications/3234075_1.pdf> accessed 15 June 2018, 6; Ménière (n 4) 10; Tsai and Wright (n 30) 161; Jorge L Contreras, 'Global Markets, Competition, and FRAND Royalties: The Many Implications of Unwired Planet v Huawei' (2017)
} 
F/RAND commitments are imprecise for practical reasons and detailed licenses for SEPs are often determined through bilateral negotiations between a SEP holder and an implementer. ${ }^{62}$ Although it has been debated whether F/RAND commitments are or should be enforceable as contractual commitments by implementers acting as third party beneficiaries, ${ }^{63}$ a popular belief is that they are.$^{64}$ For instance, in Unwired Planet, Justice Briss examined French law that governs ETSI's FRAND commitments and conceded that F/RAND commitments should be 'public, irrevocable and enforceable' contracts at least on grounds of public interest. ${ }^{65} \mathrm{~A} F /$ RAND commitment can be interpreted as an encumbrance on a patent. ${ }^{66}$

The interpretation of the rights and obligations of SEP holders and their enforceability depends on the content of the F/RAND commitment and the applicable law. ${ }^{67}$ In both civil law and common law traditions contracts are interpreted by looking into the intention of the parties to the contract. ${ }^{68}$ For instance, contract laws in the U.S. provide that an agreement must first be interpreted by giving effect to the common intention of the parties as expressed in the agreement, and in any case in a way which gives a reasonable, lawful, and effective meaning to the terms. ${ }^{69}$ Every word of a legal document is relevant. Similarly, French law requires that contract terms are interpreted in accordance with the common intention of the parties, or if the intention cannot be discerned, in a way which a reasonable person placed in the same situation would. ${ }^{70}$ Whereas IEEE and JEDEC's bylaws are governed by New York law, ${ }^{71}$ ETSI's bylaws are governed by French law. ${ }^{72}$ Discerning the intention of the parties to a F/RAND commitment is, however, a challenging task due to the fact that there are a wide and diverge range of industry participants who have developed the policies of SSOs. ${ }^{73}$ For the same reason, SSOs' policies do not necessarily correspond to economic theory or antitrust policy. ${ }^{74}$ Lack of contractual liability does not mean lack of antitrust liability, and vice versa.

17(1) The Antitrust Source

$<$ https://www.americanbar.org/content/dam/aba/publishing/antitrust_source/aug17_full_source.a uthcheckdam.pdf> accessed 15 June 2018, 7; Pentheroudakis and Baron (n 32) 33.

${ }^{62}$ Gilbert (n 16) 858; Pentheroudakis and Baron (n 32) 33.

${ }^{63}$ Contreras, 'Global Markets, Competition, and FRAND Royalties: The Many Implications of Unwired Planet v Huawei’ (n 61) 7.

${ }^{64}$ TCL $v$ Ericsson, (CD Cal Dec 21, 2017), at 9; Unwired Planet v Huawei [2017] EWHC 711 (Pat) (Apr 5, 2017), para 146; Microsoft v Motorola, (WD Wash Apr 25, 2013), at 5; Brooks and Geradin (n 61) 8; Mariniello (n 34) 525; Tsai and Wright (n 30) 158; Contreras, 'Global Markets, Competition, and FRAND Royalties: The Many Implications of Unwired Planet v Huawei' (n 61) 7; Pentheroudakis and Baron (n 32) 33.

${ }^{65}$ Unwired Planet v Huawei [2017] EWHC 711 (Pat) (Apr 5, 2017), para 146.

${ }^{66}$ TCL $v$ Ericsson, (CD Cal Dec 21, 2017), at 11.

${ }^{67}$ Pentheroudakis and Baron (n 32) 34; Sidak, 'Fair and Unfair Discrimination in Royalties for Standard-Essential Patents Encumbered by a FRAND or RAND Commitment' (n 59) 312.

${ }^{68}$ Brooks and Geradin (n 61) 8; Pentheroudakis and Baron (n 32) 34.

${ }^{69}$ Restatement (Second) of Contracts (Am Law Inst 1981), S\$ 201-203; Reda v Eastman Kodak. (NY

App Div 1996), at 557.

${ }^{70}$ French Civil Code, Art 1188.

71 JEDEC Manual (2017) \ 8.2.10; IEEE-SA Bylaws (2017) \ 3.

${ }^{72}$ ETSI IPR Policy (2017) $₫ 12$.

${ }^{73}$ Brooks and Geradin (n 61) 8; Jorge L Contreras, 'A Brief History of FRAND: Analyzing Current Debates in Standard Setting and Antitrust Through a Historical Lens' (2015) 80 Antitrust LJ 39, 73.

${ }^{74}$ Brooks and Geradin (n 61) 8. 


\subsection{IEEE, JEDEC AND ETSI'S COMMITMENTS}

IEEE, JEDEC, and ETSI aim to ensure that SEPs are available to all implementers on F/RAND license terms and oblige their members to establish a licensing commitment. However, their bylaws do not provide a clear definition of the ND prong of F/RAND nor do they explain in detail the rights and obligations of F/RANDcommitted SEP holders. The notions of discrimination or non-discrimination have not received much attention in the SSOs' bylaws, but some implications can be drawn from the wordings of the policy documents.

The wordings of IEEE and JEDEC's policy documents are similar. They impose a qualified prohibition against discriminatory license terms. IEEE requires SEP holders to declare that they 'will make available a license for Essential Patent Claims to an unrestricted number of Applicants on a worldwide basis without compensation or under Reasonable Rates, with other reasonable terms and conditions that are demonstrably free of unfair discrimination. ${ }^{.75}$ In a similar way, JEDEC requires SEP holders to agree that '[a] license will be offered, to applicants desiring to utilize the license for the purpose of implementing the JEDEC Standard under reasonable terms and conditions that are free of any unfair discrimination. ${ }^{76}$ ETSI formulates its licensing requirements slightly differently from IEEE and JEDEC. ETSI requests SEP holders to be 'prepared to grant irrevocable licences on fair, reasonable and nondiscriminatory ('FRAND') terms and conditions' to implementers of ETSI's standards. ${ }^{77}$

Based on the wordings of the SSOs' policy documents and the incorporation of the word 'fair', it may be argued that IEEE and JEDEC set 'RAND' commitments whereas ETSI sets 'FRAND' commitments, and that they impose different obligations on SEP holders. ${ }^{78}$ On the one hand, the bylaws of IEEE and JEDEC require SEP holders to license on terms that are free of any unfair discrimination as opposed to a mere requirement of non-discrimination. The wording implies that discriminatory terms can be fair. ${ }^{79}$ In other words, differential treatment of licensees might be justified in some circumstances. On the other hand, ETSI's bylaws seem to prohibit all forms of discrimination in license terms as the non-discrimination requirement is not mitigated by fairness. ${ }^{80}$ Be that as it may, it does not necessarily follow that ETSI's bylaws prohibit all forms of discrimination nor that they effectively oblige SEP holders to license on identical license terms. It has been argued that many SSOs with unqualified non-discrimination requirements allow some flexibility for SEP holders to

\footnotetext{
75 IEEE-SA Bylaws (2017) \6.2.

${ }^{76}$ JEDEC Manual (2017) \$ 8.2.5.

${ }^{77}$ ETSI IPR Policy (2017) \6.1.

${ }^{78}$ Sidak, 'Fair and Unfair Discrimination in Royalties for Standard-Essential Patents Encumbered by a FRAND or RAND Commitment' (n 59) 309.

${ }^{79}$ ibid.

${ }^{80}$ Contreras, 'Global Markets, Competition, and FRAND Royalties: The Many Implications of Unwired Planet v Huawei’ (n 61) 6.
} 
offer and negotiate differential license terms. ${ }^{81}$ In fact, historical documentation of ETSI's policy reveals that the non-discrimination obligation of ETSI's FRAND commitment means less than a Most Favoured Licensee -clause, ${ }^{82}$ and requires no identical license terms for all implementers. ${ }^{83}$ The commitments required by IEEE, JEDEC, and ETSI all seem to allow SEP holders to offer and negotiate differential license terms.

IEEE is the only one of the three SSOs to specify how to determine royalty rates. IEEE has introduced an engagement for SEP holders to use the smallest saleable patent practicing unit ('SSPPU', or 'the smallest product priced in the marketplace that contains the substantive aspects of the invention, ${ }^{84}$ or 'the smallest salable infringing unit with close relation to the claimed invention ${ }^{85}$ ) as the royalty base in all licenses, ${ }^{86}$ which was approved by the DOJ. ${ }^{87}$ Accordingly, royalties should not be based on profits of an entire end-product. However, several members have stated that they will not comply with the restriction. ${ }^{88}$ The obligation to use the SSPPU is controversial, as the SSPPU concept seems to be mainly used in the context of patent infringement jury trials, ${ }^{89}$ and it might reduce incentives to innovate and participate in standard setting.

\section{DRAWING THE BOUNDARIES OF ANTI-COMPETITIVE PRICE DISCRIMINATION IN THE US AND THE EU}

Although antitrust norms on differential pricing are distinguished from the norms in the context of standard setting, they are both relevant for the interpretation of whether SEP holders have a right to set differential royalties to different licensees, because SSOs and antitrust law share the same objective: prevention of abusive use of market power by patentees. This chapter analyses the U.S. and EU competition policies on differential pricing and patentees' licensing practices, seeking to draw the boundaries of anti-competitive discriminatory pricing.

The first section discusses the rationale behind prohibiting differential pricing in general, after which the focus shifts on the competition policies of the U.S. and the EU, scrutinizing the attitudes towards differential pricing and licensing practices of patentees. The second section provides an overview of U.S. antitrust law and the prohibition of monopolization, and the third section an overview of EU competition

\footnotetext{
${ }^{81}$ Sidak, 'Fair and Unfair Discrimination in Royalties for Standard-Essential Patents Encumbered by a FRAND or RAND Commitment' (n 59) 315.

82 Brooks and Geradin (n 61) 32-33.

83 ibid 33; Sidak, 'Fair and Unfair Discrimination in Royalties for Standard-Essential Patents Encumbered by a FRAND or RAND Commitment' (n 59) 314.

${ }^{84}$ Gregory K Leonard and Mario A Lopez, 'Determining RAND Royalty Rates for Standard-Essential Patents' (2014) 29(1) Antitrust Magazine 86, 90.

${ }^{85}$ LaserDynamics v Quanta Computer, (Fed Cir 2012), at 67.

86 IEEE-SA Bylaws (2017) \6.1.

${ }^{87}$ Letter from Renata B Hesse (Assistant Attorney General, US DOJ) to Michael A Lindsay (Dorsey \& Whitney LLP), (February 2, 2015).

88 Andrew Lloyd, 'Ericsson and Nokia the latest to confirm that they will not license under the new IEEE patent policy' (IAM blog, April 2015) < http:/ / www.iam-

media.com/Blog/Detail.aspx?g=d07d0bde-ebd6-495a-aa72-4eecb9dac67d > accessed 15 June 2018.

${ }^{89}$ Ericsson v D-Link Sys, (Fed Cir 2014), at 1226.
} 
law and the prohibition of abuse of dominance. Lastly, the fourth section examines the existence of compulsory licensing in U.S. and EU law in order to analyse to what extent patentees may generally exclude others from practicing the patented technology and discriminate between willing licensees. Despite having the same objectives, the competition regimes of the U.S. and the EU diverge. The level of the burden of proof borne by the authorities seeking to demonstrate possible anti-competitive effects of conduct is essentially a policy decision - it depends on the employed economic theory. The standard appears to be lower in the EU than in the U.S.

\subsection{RATIONALE BEHIND PROHIBITNG DIFFERENTIAL PRICING}

Before looking into the reasons why differential pricing may be prohibited, it is important to define what price discrimination is in the traditional sense. The economic concept of price discrimination often refers to different ratios of price to marginal costs between customers. ${ }^{90}$ Price discrimination thus includes pricing practices that do not take into account the seller's costs of providing the product that varies among customers. ${ }^{91}$ Patent licensing differs from provision of tangible products in that patents involve high upfront costs related to R\&D efforts and relatively low marginal costs of licensing, such as monitoring costs and patent maintenance and enforcement fees. ${ }^{92}$ Therefore, cost differences may not be as relevant in the context of patent licensing. ${ }^{93}$ However, the bottom line is that discrimination arises where dissimilar terms and conditions are applied to similar transactions or similar terms and conditions are applied to dissimilar transactions.

Economically speaking, differential pricing can increase efficiency and improve consumer welfare. ${ }^{94}$ It may, however, be unlawful when it may harm competition. Price discrimination may cause either primary line or secondary line injury to competition: it may have the effect of foreclosing the company's competitors on the same market or of distorting the company's customers' competitiveness. ${ }^{95}$ In EU law, even mere harm to innovation without obstructing competitiveness may suffice to trigger antitrust liability. ${ }^{96}$ Some argue that the risk of vertically integrated SEP holders' anticompetitive conduct is, or should be, the primary justification for the ND prong of F/RAND. ${ }^{97}$

The weight of the price discrimination concern depends on the company's position in the market. Patentees are generally legally allowed to maximize their income

\footnotetext{
${ }^{90}$ Layne-Farrar and Stuart (n 17) 44; Sidak, 'Fair and Unfair Discrimination in Royalties for StandardEssential Patents Encumbered by a FRAND or RAND Commitment' (n 59$) 353$.

${ }^{91}$ Layne-Farrar (n 53) 814; Sidak, 'Fair and Unfair Discrimination in Royalties for Standard-Essential

Patents Encumbered by a FRAND or RAND Commitment' (n 59) 336.

${ }^{92}$ Layne-Farrar (n 53) 815.

93 ibid.

94 Swanson and Baumol (n 4) 25-26; Layne-Farrar (n 53) 815; Carlton and Shampine (n 40) 549; Jones and Sufrin (n 4) 381; Layne-Farrar and Stuart (n 17) 44; Sidak, 'Fair and Unfair Discrimination in Royalties for Standard-Essential Patents Encumbered by a FRAND or RAND Commitment' (n 59) 337.

${ }^{95}$ Jones and Sufrin (n 4) 381.

${ }_{96}$ Case T-201/04 Microsoft [2007] ECLI:EU:T:2007:289.

${ }^{97}$ Swanson and Baumol (n 4) 27.
} 

by charging differential royalties to licensees, ${ }^{98}$ and they generally do so. ${ }^{99}$ Patentees, including SEP holders, tend to engage in price discrimination by charging differential royalties according to the nature of the devices that the licensees intend to manufacture. ${ }^{100}$ Nevertheless, the incentives for charging differential license fees vary depending on the type of the patentee. Patentees can be distinguished into two types: (1) companies operating only in the upstream market, whose only source of income is licensing revenue, and (2) vertically integrated companies, or companies operating in both the upstream and the downstream market, whose sources of income are both licensing revenue and revenue from sales in the downstream market. It has been argued that vertically integrated companies have stronger incentives to discriminate in licensing. ${ }^{101}$ Whereas non-integrated companies' incentive is only to increase licensing revenue, the incentive for vertically integrated companies may be to favour their own subsidiaries and foreclose rivals in the downstream market. ${ }^{102}$ The margin squeeze theory has been employed under U.S. and EU law where the vertically integrated monopolist has charged discriminatory wholesale prices to its competitors in the downstream market. ${ }^{103}$

\subsection{U.S. ANTITRUST POLICY AND THE ISSUE OF 'MONOPOLIZATION'}

Like intellectual property ('IP') law, antitrust law is unified throughout the U.S., and limitations on patent related conduct come equally from the two fields of law. U.S. antitrust law is developed by multiple institutions. There are two enforcement agencies, the Federal Trade Commission ('FTC') and the DOJ, whose enforcement policies are subject to judicial review. Furthermore, antitrust law is partly driven by private litigation, which is incentivized by the provision of treble damages. ${ }^{104}$

One of the main statutes of U.S. antitrust law is the Sherman Act of 1890, which was seemingly passed as a response to powerful and anti-competitive oil and railroad companies that were formed as trusts. ${ }^{105}$ Monopoly power has been considered injurious to the public due to possible higher prices, decreased output, and deterioration in product quality. ${ }^{106}$ The Chicago competition theory has had a great influence on the U.S. antitrust policy, although the market structure - conduct performance -paradigm of the Harvard School has remained relevant for antitrust analysis. ${ }^{107}$ The Chicago competition theory is part of Chicago economics, which promotes neoclassical free-market economics and holds that people are rational and markets self-correcting. ${ }^{108}$ According to the theory, the only aim of antitrust law should

\footnotetext{
${ }^{98}$ See, for instance, USM v SPS Techs, (7th Cir 1982), at 512.

${ }^{99}$ Layne-Farrar (n 53) 813.

100 ibid 7.

101 ibid 3; Layne-Farrar and Stuart (n 17) 17.

102 Layne-Farrar (n 53) 824-25.

${ }_{103}$ C-280/08 Deutsche Telekom AG [2010]; Town of Concord v Boston Edison (1st Cir 1990).

10415 USC, \15(a).

105 Jones and Sufrin (n 4) 29.

106 Standard Oil v United States, 221 US 1 (1911), at 52.

107 Jones and Sufrin (n 4) 14.

108 ibid.
} 
be the pursuit of allocative efficiency. ${ }^{109}$ Thus, governmental interference is desirable only when harm to the overall efficiency is demonstrated. Economic reasoning has penetrated U.S. antitrust law through neoclassical economics of the Chicago School. ${ }^{110}$ Indeed, economic theory and econometrics are an integral part of U.S. antitrust law. ${ }^{111}$ Practices distorting competition are not necessarily considered violating antitrust law when they promote innovation in the long term. ${ }^{112}$ Effects-based proof is required for a violation to be found.

\section{2[a] Monopolization and Price Discrimination}

Section 2 of the Sherman Act on monopolization applies to unilateral anti-competitive conduct. The U.S. Supreme Court has emphasized that the mere possession of monopoly power is not unlawful, but an important element of the free-market system which attracts business acumen in the first place. ${ }^{113}$ Monopoly may be obtained lawfully by virtue of 'superior skill, foresight and industry' and thus the courts have stressed that ' $[\mathrm{t}]$ he successful competitor, having been urged to compete, must not be turned upon when he wins. ${ }^{, 114}$ Liability for monopolization requires two elements: '(1) the possession of monopoly power in the relevant market and (2) the willful acquisition or maintenance of that power' not resulting from 'a superior product, business acumen, or historic accident. ${ }^{, 115}$ Demonstrating liability for attempted monopolization requires proof that (1) 'the defendant engaged in predatory or anticompetitive conduct' with (2) 'a specific intent monopolize' and that there is (3) 'a dangerous probability of achieving monopoly power. ${ }^{116}$

Section 2 of the Clayton Act, as amended by the Robinson-Patman Act, expressly prohibits price discrimination. Section 2(a) of the Robinson-Patman Act prohibits discrimination in price between purchasers of commodities of like grade and quality which may substantially lessen competition or create a monopoly. The Act distinguishes between primary and secondary line injury to competition. ${ }^{117}$ There are two affirmative defences for price discrimination: (1) cost differences in manufacture, sale or delivery of the commodity; and (2) differentiation as a good faith response to the equally low prices of a competitor. ${ }^{118}$ Nevertheless, the economic soundness of the Robinson-Patman Act prohibition has been widely questioned, ${ }^{119}$ and although the act has not been repealed it has been disregarded by the U.S. antitrust agencies. ${ }^{120}$

The analysis of conduct begins with the market definition, which includes both the product market and the geographic market. The boundaries of the product market

\footnotetext{
109 ibid 15.

${ }_{110}$ Devlin (n 3$)$ 106-107.

111 ibid 106.

112 ibid 109.

113 Verizon Communications v Law Offices of Curtis v Trinko, 540 US 398 (2004).

114 United States v Aluminum (2d Cir 1945), at 430.

115 United States v Grinnell, 384 US 563 (1996), at 570-71.

116 Spectrum Sports v McQuillan, 506 US 447 (1993), at 456.

117 See, for instance, Volvo Trucks v Reeder-Simco GMC, 546 US 164 (2006), at 176.

118 Texaco v Hasbrouck, 496 US 543 (1990), at 555-556.

${ }^{119}$ Layne-Farrar and Stuart (n 17) 57.

120 ibid 58.
} 
are determined by the reasonable interchangeability of use or the cross-elasticity of demand between the product and its substitutes. ${ }^{121}$ The geographic market refers to the geographic area in which consumers can find alternative sources of the product and in which there is competition. ${ }^{122}$ The same principles are used for technology markets. ${ }^{123}$ Monopoly power refers to 'the power to control prices or exclude competition, ${ }^{124}$ which often equals to a market share higher than 65 per cent. ${ }^{125}$ However, no precise threshold has been established, and market share is not the only indicator of monopoly power. Market power depends on the industry's characteristics, such as barriers to entry. ${ }^{126}$ Once monopoly power has been established, it is determined whether the defendant had acquired or maintained that power through anti-competitive conduct. Yet conduct with anti-competitive effects may be justified by economic efficiency. ${ }^{127}$

\section{2.[b] Monopolization by Patentees}

Patents are not presumed to confer market power upon patentees, and in case a patent is found to confer market power it does not in itself violate antitrust law. ${ }^{128}$ It is possible for a patentee to monopolize a technology market and a patent may form a single technology market when there is definite demand for the technology that is not substitutable. The FTC has recognized the relevant market for a SEP to be a single technology market and concluded that a SEP holder is a monopolist. ${ }^{129}$ The Third Circuit came to the same conclusion in Broadcom v. Qualcomm in 2007, holding that the incorporation of a patent into a standard and the subsequent industry lock-in makes the relevant market congruent with the patented technology. ${ }^{130}$ Nonetheless, defining the market for SEPs is complex and the law is bound to evolve.

Although patents were traditionally considered an exception to the rule against monopolies, antitrust law has operated to ensure that a patent is not used to gain market power going beyond the scope of the patent grant. ${ }^{131}$ In accordance with the patent misuse -doctrine, the monopoly of the patent may not be extended to derive benefits not attributable to the use of the patent. ${ }^{132}$ The defence of patent misuse has been narrowed, however, as the Federal Circuit held in 2010 that misuse exists only if the anti-competitive conduct involves the patent being enforced and a substantial anti-

121 Brown Shoe v United States, 370 US 294 (1962), at 325.

122 Morgenstern $v$ Wilson, (8th Cir 1994), at 1296.

${ }^{123}$ US DOJ and FTC, Antitrust Guidelines for the Licensing of Intellectual Property (Jan. 12, 2017), \ 3.2.2.

${ }_{124}$ United States v E I du Pont de Nemours, 351 US 377 (1956), at 391.

125 Image Technical Services v Eastman Kodak, (9th Cir 1997), at 1206.

126 Rebel Oil v At Richfield, (9th Cir 1995), at 1434.

127 United States v Microsoft, (DC Cir 2001), at 59.

${ }^{128}$ III Tool Works v Independent, 547 US 28 (2006); US DOJ and FTC, Antitrust Guidelines for the Licensing of Intellectual Property (Jan 12, 2017), \$ 2.2.

${ }^{129}$ In re Motorola Mobility LLC \& Google Inc, FTC Docket No C-4410 (2013), complaint, paras 20-21.

130 Broadcom v Qualcomm, (3d Cir 2007), at 315.

131 See, for instance, ISO v Xerox, 203 F3d 1322 (2000), at 1327.

132 Zenith Radio v Hazeltine Research, 395 US 100 (1969), at 136; Morton Salt v GS Suppiger, 314 US 488 (1942). 

competitive effect lies outside the scope of that patent grant. ${ }^{133}$ Patents do not confer privilege or immunity to violate antitrust law; ${ }^{134}$ today, even conduct falling within the scope of the patent appears to be subject to antitrust scrutiny. For instance, in Actavis, the Supreme Court held that pay-for-delay agreements may violate the Sherman Act even though such agreements arguably fall within the scope of the patent. ${ }^{135}$

\subsection{EU COMPETITION LAW AND THE EXERCISING OF PATENTS}

Due to the lack of unified rules of contract law or IP law, competition law plays a particularly important role in the EU when it comes to exercising patents. EU competition law is developed mainly by the Commission: the Commission sets the competition policy and oversees its enforcement in cooperation with the National Competition Agencies of the member states. The investigative, prosecutorial, and adjudicatory functions are not separated. The Commission's decisions can, however, be appealed to the Court of Justice of the European Union ('CJEU').

Article 3(3) of the Treaty on the European Union provides that the EU is to establish an internal market, and that market includes a system ensuring that competition is not distorted. ${ }^{136}$ According to the CJEU, the competition rules exist to prevent restrictions on competition to the detriment of the public interest, individual undertakings, and consumers. ${ }^{137}$ They seek to protect the structure of the market, and thus competition as such. ${ }^{138}$ EU competition law has been developed with a skeptical attitude towards free markets with little governmental intervention. ${ }^{139}$ Competition law has operated as a tool of public policy. ${ }^{140}$ The Freiburg School of Ordoliberalism provided a framework for the formation of EU competition policy. ${ }^{141}$ Ordoliberalism promoted a fragmented market structure with and, importantly, freedom of choice. ${ }^{142}$ Many Ordoliberal principles such as the protection of individual economic freedom are reflected in the case law and the decisional practice of the EU institutions, especially with regard to Article 102 of the Treaty on the Functioning of the European Union ('TFEU'). ${ }^{143}$ As EU competition law appears to protect not only competition but also competitors, it also reflects a structuralist view of competition similarly to the Harvard School's structure - conduct - performance -paradigm. ${ }^{144}$ Even though Ordoliberalism was based on social values, ${ }^{145}$ economic efficiency arguments play a role in EU

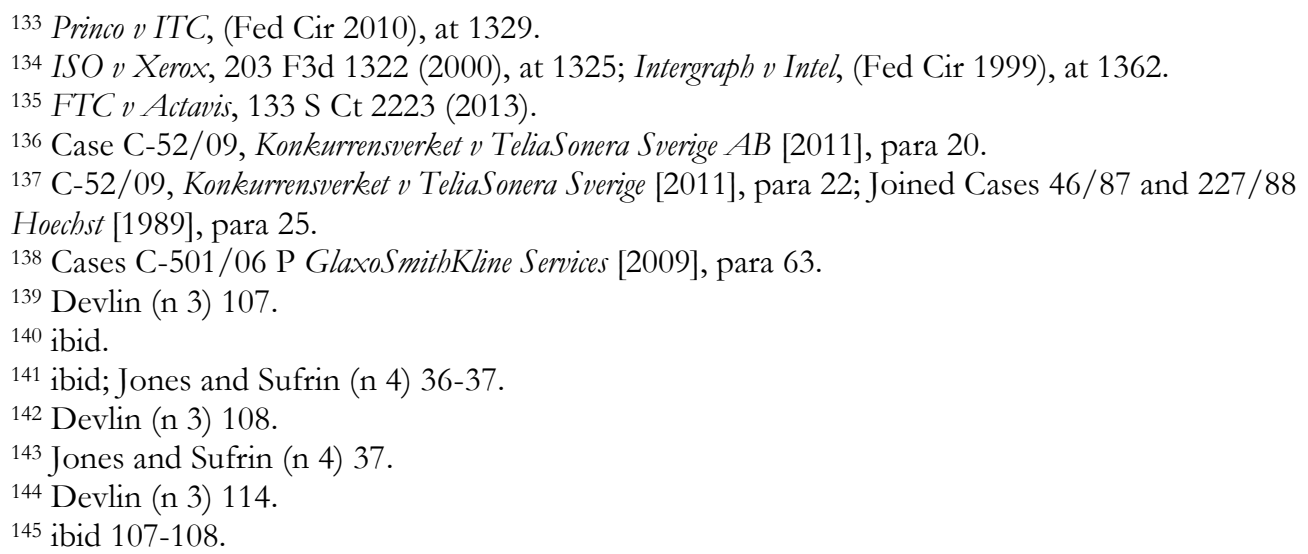


competition policy of today. In fact, in the 1990s, the Commission began to adopt a more economic approach and reformed the enforcement of EU competition law. ${ }^{146}$

\section{3. [a] Abuse of Dominance and Price Discrimination}

Article 102 of the TFEU prohibits abuse of dominant position within the internal market in so far as it may affect trade between member states. It is not concerned with market power as such, but with the anti-competitive means of obtaining, maintaining, and enhancing it. Dominance comes with a so-called 'special responsibility' not to distort competition. ${ }^{147}$ There is no simple definition for the concept of abuse, but it refers to behavior of a dominant undertaking which influences the structure of a market by weakening the degree of competition. ${ }^{148}$ Abuse may be exploitative, exclusionary and/or discriminatory. Nonetheless, liability under Article 102 may be escaped by proving objective necessity or efficiency enhancing effects of the abusive conduct as a justification. ${ }^{149}$

Article 102(c) of the TFEU expressly prohibits 'applying dissimilar conditions to equivalent transactions with other trading parties, thereby placing them at a competitive disadvantage.' Price discrimination by a dominant undertaking does not automatically equal a violation of competition law, ${ }^{150}$ but it may trigger Article 102 when there is a possibility that it causes primary and/or secondary line injury. ${ }^{151}$ Article 102(c) deals mainly with secondary line injury, ${ }^{152}$ but it has been applied in situations of primary line injury as well. ${ }^{153}$ Discrimination in a downstream market might also fall under Article 102(b) of the TFEU prohibiting abuse of 'limiting production, markets or technical development to the prejudice of consumers. ${ }^{154}$ Nevertheless, the CJEU recognizes that presumptively abusive discriminatory treatment may escape application of Article 102 if it has an 'objective justification. ${ }^{155}$ The question of objective justification is actually considered at the same time as the question of comparable transactions. ${ }^{156}$ Comparability of transactions depends on factors such as the nature of products involved and the consumer's perception of the products, ${ }^{157}$ costs incurred by the seller, ${ }^{158}$ and timing of transactions. ${ }^{159}$ Engaging in price discrimination to meet

\footnotetext{
${ }^{146}$ See, for instance, Council Regulation (EC) No 1/2003 on the implementation of the rules on competition laid down in Articles 81 and 82 of the Treaty, 2013 OJ L 1; Jones and Sufrin (n 4) 37-38. ${ }_{147}$ Case T-201/04 Microsoft [2007], para 229; Case 322/81, NV Nederlandsche Banden-Industrie Michelin [1983], para 57.

148 Case 85/76 Hoffmann-La Roche [1979], para 91.

${ }^{149}$ Commission Communication, Guidance on the Commission's enforcement priorities in applying Article [102 TFEU] to abusive exclusionary conduct by dominant undertakings [2009] OJ C45/02, SS 28-30.

${ }^{150}$ Case C-209/10, Post Danmark A/S v Konkurrenceradet, EU:C:2012:172, para 30.

${ }^{151}$ See, for instance, Case C-95/04 P, British Airways [2007], paras 144-145.

152 Layne-Farrar and Stuart (n 17) 2-3.

153 See, for instance, Case 85/76, Hoffmann-La Roche [1979], para 90.

${ }^{154}$ Layne-Farrar and Stuart (n 17) 3.

155 C-209/10, Post Danmark. A/S v Konkurrencerådet, EU:C:2012:172, paras 40-42.

${ }^{156}$ Layne-Farrar and Stuart (n 17) 16.

157 ibid 5, 7; Case 27/76 United Brands [1978], paras 224-225.

158 Case T-301/04 Clearstream [2009], para 186; Layne-Farrar and Stuart (n 17) 8.

159 ABG/Oil Companies (Case IV/28.841) Commission Decision 77/327/EEC [1977] OJ L 117/1; Layne-Farrar and Stuart (n 17) 11.
} 
competitors' prices in the market might result in secondary line discrimination and trigger Article 102. ${ }^{160}$

Establishing dominance begins with examining the structure of the market. ${ }^{161}$ According to the Commission, market definition is a tool to identify and define the competitive constraints, which includes both a product and a geographic dimension. ${ }^{162}$ The relevant product market comprises products that are interchangeable with each other because of the characteristics, prices and intended use. ${ }^{163}$ The geographic market refers to the area in which the undertakings are involved, and where the conditions of competition are sufficiently homogenous and distinguishable. ${ }^{164}$ The so-called Small but Significant and Non-Transitory Increase in Price -test operates a tool for estimating substitutability, which asks whether the customer would switch to available substitutes or suppliers in response to a hypothetical small (in the range 5 to 10 per cent) but permanent relative price increase in the products and areas. ${ }^{165}$ If substitution renders the price increase unprofitable for the company, the substitutes and areas are included in the relevant market. ${ }^{166}$ However, in the absence of sufficient data, the Commission makes use of more impressionistic assessments. ${ }^{167}$ The Commission uses the same principles for defining technology markets. ${ }^{168}$ The CJEU defines a dominant position as:

'position of economic strength enjoyed by an undertaking which enables it to prevent effective competition being maintained on the relevant market by giving it the power to behave to an appreciable extent independently of its competitors, customers and ultimately of its consumers. ${ }^{169}$

According to the Commission, market power depends mainly on three factors: market share, barriers to entry, and countervailing buyer power. ${ }^{170}$ Large market shares are considered evidence of dominance. ${ }^{171}$

\footnotetext{
160 Layne-Farrar and Stuart (n 17) 41.

${ }^{161}$ Case 27/76 United Brands [1978], para 67.

162 Commission Notice on the definition of the relevant market for the purposes of community competition law [1997] OJ C372/03, para 2.

163 ibid para 7.

164 ibid para 8.

165 ibid paras $15,17$.

166 ibid para 17.

${ }^{167}$ See, for instance, Case 27/76 United Brands [1978], paras 30-31.

${ }^{168}$ Commission Regulation (EU) No 316/2014 on the application of Article 101(3) of the Treaty on the Functioning of the European Union to categories of technology transfer agreements, 2014 OJ L 93/17, Art 1(1)k.

${ }^{169}$ Case 27/76 United Brands [1978], para 65.

${ }^{170}$ Commission Communication, Guidance on the Commission's enforcement priorities in applying Article [102 TFEU] to abusive exclusionary conduct by dominant undertakings [2009] OJ C45/02, S 12.

${ }^{171}$ Case 85/76 Hoffmann-La Roche [1979], para 41.
} 


\section{3.[b] Abuse of Dominance by Patentees}

Similarly to U.S. law, a patent is not considered to place the patentee in a dominant position in itself. ${ }^{172}$ However, if there are no substitutes for the technology, the patent may create a single technology market, for example when a license is indispensable for competition in the downstream product market. ${ }^{173}$ This is generally the case with SEPs. ${ }^{174}$ Nevertheless, high market shares are not necessarily a sufficient indication of market power in high-tech markets due to short innovation cycles. ${ }^{175}$

Using patents to strengthen a dominant position so as to, for instance, delay or prevent a competitor's entry into the market constitutes abuse under Article 102 of the TFEU. Patents granted by the legal systems of the member states may be in conflict with the market integration objective of the EU. Article 345 of the TFEU provides protection against EU law interfering with national systems of property ownership, but the CJEU has specified that the protection is limited. EU competition rules may supersede national patent law. The Commission recognizes that although patents exclude others from exploiting the invention without consent, they are not immune from competition law intervention. ${ }^{176}$ The CJEU has traditionally distinguished between the existence and exercise of a patent. Essentially, competition law governs matters relating to the exercise of patents, the commercial use of those rights, whereas patent ownership falls outside the scope of competition law. This distinction was initially made in the 1966 decision Consten and Grundig, where the CJEU struck down a license agreement which limited competitiveness of third parties. ${ }^{177}$ The Court argued that the artificial isolation and maintenance of separate markets distorts competition in the internal market as such. ${ }^{178}$ In the decisions following Consten and Grundig, the CJEU formed the concept of the 'specific subject matter' of the intellectual property right ('IPR'). ${ }^{179}$ According to the CJEU, use of an IPR in a manner which goes beyond the specific subject matter of the right constitutes an 'exercise' of that right. For the purposes of EU law, the specific subject matter of a patent is 'to ensure to the holder, so as to recompense the creative effort of the inventor, the exclusive right to utilize an invention with a view to manufacture and first putting into circulation of industrial products either directly or by the grant of licenses to third parties. ${ }^{180}$ It may be inferred that the specific subject matter of a patent is synonymous with the scope of the patent. For example, in Windsurfing, the CJEU held that restrictions imposed by a patentee on licensees' freedom over a product outside the scope of the patents violate competition

172 Cases C-241/91 P and C-242/91 P RTE and ITP (Magill) [1995], para 46.

${ }^{173}$ See, for instance, Cases C-241/91 P and C-242/91 P RTE and ITP (Magill), [1995], paras 24, 47.

174 See, for instance, Google/Motorola Mobility (Case COMP/M.6381) Commission Decision [2012] OJ

C 75/1, para 54; Motorola Mobility (Case AT.39985) Commission Decision [2014] OJ C 344/6, para 19.

175 Case T-79/12 Cisco ECLI:EU:T:2013:635, para 69.

176 Commission Communication, Guidelines on the application of Article 101 of the Treaty on the

Functioning of the European Union to technology transfer agreements [2014] OJ C 89/03, paras 6-7.

177 Cases C-56/64 etc Consten \& Grundig [1966], at 341-342.

178 ibid 343.

${ }^{179}$ See, for instance, Case C-193/83 Windsurfing International [1986], para 45; Case 78/70, Deutsche

Grammophon Gesellschaft v Metro-SB-Großmorkte GmbH, [1971], para 11.

${ }^{180}$ Case 15/74 Centrafarm v Sterling Drug [1974], para 9. 
law. ${ }^{181}$ Nevertheless, even conduct within the scope of the patent may breach EU competition law in certain circumstances. One example of such circumstances is the existence of a duty to license.

\subsection{COMPULSORY LICENSING IN THE US AND EU: UNDERSTANDING THE DIVERGENCE ON THE FREEDOM TO CONTRACT}

It has been debated whether antitrust law should require a patentee to supply its infrastructure, its essential facility, to its competitors in order to facilitate competition and innovation. Certainly, such a duty to license is contrary to the very idea of a patent. Moreover, compulsory licensing and liability rules may be inefficient and encourage free-riding as companies failing to gain access may abuse the legal process. ${ }^{182}$ Without a duty to license, a patentee in a dominant position in the market may foreclose competition and prevent follow-on innovation. ${ }^{183}$ Refusal to deal may be particularly problematic in two situations: first, when a dominant provider of a primary product hinders competition in secondary markets for complementary products and services by refusing to allow interoperability; ${ }^{184}$ and second, when monopolistic components in network industries block access for entrants. ${ }^{185}$ Consequently, compulsory licensing may be imposed as a remedy to anti-competitive conduct or to address a pressing public need. ${ }^{186}$

Compulsory licensing orders and the accompanying commitments are similar to commitments in the standard setting context in respect of content and implementation. ${ }^{187}$ In fact, F/RAND commitments in standard setting originate from U.S. antitrust orders. ${ }^{188}$ The rationale is the same, namely to allow competition and entry into the market. Significantly, those commitments entail licensing on the same standard of terms: F/RAND. ${ }^{189}$ Therefore, analyses of antitrust orders may be helpful when interpreting and enforcing F/RAND commitments in the standard setting context.

The question of compulsory licensing is familiar to both U.S. and EU law, but the answers differ between the legal systems. EU law allows interference into a patentee's right to exclude more easily. In his speech in March 2018, Assistant Attorney General Delrahim stressed that SSOs and courts should be very cautious before adopting rules that restrict patentees' right to exclude 'or - even worse - amount to a

\footnotetext{
${ }^{181}$ Case C-193/83 Windsurfing International [1986], paras 45-51.

182 Devlin (n 3) 239.

183 ibid 231.

184 ibid 240-241.

185 ibid 241

${ }^{186}$ Contreras, 'A Brief History of FRAND: Analyzing Current Debates in Standard Setting and Antitrust Through a Historical Lens’ (n 73) 45.

187 ibid 46.

188 Jorge L Contreras and Anne Layne-Farrar, 'Non-Discrimination and FRAND Commitments' in Jorge L Contreras (ed), The Cambridge Handbook of Technical Standardization Law, Volume 1: Antitrust and Patents (CUP, 2017) 187.

${ }^{189}$ Contreras, 'A Brief History of FRAND: Analyzing Current Debates in Standard Setting and Antitrust Through a Historical Lens’ (n 73) 46.
} 

de facto compulsory licensing scheme. ${ }^{, 190}$ The CJEU has established a duty to license, and the existence - exercise distinction has diminished. As dominant undertakings are imposed a special responsibility not to distort effective competition, their ability to exclude rivals is very limited in EU law. Exclusionary use of property, as opposed to productive use, is placed under scrutiny. As noted by former Commissioner Neelie Kroes, dominant companies have a great responsibility to allow competition especially in high-tech industries. ${ }^{191}$ Former Commissioner Joaquín Almunia has also emphasized that software interoperability remains central to the Commission's enforcement practice. ${ }^{192}$

\section{4. [a] Duty to Deal in U.S. Law}

U.S. law is averse to compulsory dealing. In accordance with the decades-old Colgate doctrine, a company has a freedom to decide with whom to contract and on what terms. ${ }^{193}$ It applies even to monopolists. Nevertheless, a duty to deal exists in U.S. law at least in relation to tangible infrastructures.

The Supreme Court recognized a duty to deal in 1912 Terminal Railroad, in which a terminal association that was controlled by competing railroads breached Sections 1 and 2 of the Sherman Act for conspiring to refuse granting railroad access to competitors and attempting to monopolize commerce. ${ }^{194}$ The Court ordered the defendants to open membership in the association to any other railroads on 'just and reasonable terms' and place applying companies upon 'a plane of equality in respect of benefits and burdens,' and to allow use of their terminal facilities 'upon such just and reasonable terms and regulations. ${ }^{195}$ In its later case law, the Supreme Court appears to have established an essential facilities doctrine implicitly. In 1973 decision Otter Tail, a naturally monopolistic company had refused to sell power at wholesale or to transmit electricity over its lines to municipalities wishing to construct their own electrical grids and was thus found to restrict competition at the rail level in violation of Section $2{ }^{196}$ More recently, the Court found a Section 2 violation in Aspen Skiing on the basis of a dominant company terminating cooperation with its competitor by closing access to a network. ${ }^{197}$ The dominant company failed to provide any efficiency justification and was found 'willing to sacrifice short-run benefits and consumer goodwill in exchange

\footnotetext{
190 US DOJ, Assistant Attorney General Makan Delrahim, ‘The 'New Madison’ Approach to Antitrust and Intellectual Property Law' (Philadelphia, 16 March 2018)

<https://www.justice.gov/opa/speech/assistant-attorney-general-makan-delrahim-delivers-keynoteaddress-university> accessed 15 June 2018.

${ }^{191}$ European Commission, 'Antitrust: Commission welcomes CFI ruling upholding Commission's decision on Microsoft's abuse of dominant market position' (MEMO/07/359, Brussels, 17 September 2007) <http://europa.eu/rapid/press-release_MEMO-07-359_en.htm> accessed 15 June 2018. 192 European Commission, Joaquín Almunia, 'Higher Duty for Competition Enforcers' (SPEECH/12/453 International Bar Association Antitrust Conference, Madrid, 15 June 2012)

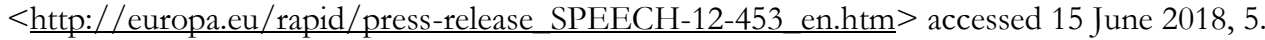
193 United States v Colgate, 250 US 300 (1919), at 307.

194 United States v Terminal Railroad Association, 224 US 383 (1912).

195 ibid at 411.

196 Otter Tail Power Co v United States, 410 US 366 (1973).

197 Aspen Skiing v Aspen Highlands Skiing, 472 US 585 (1985).
} 
for a perceived long-run impact on its smaller rival. ${ }^{, 198}$ A duty to deal arose exceptionally on the basis of termination of a prior course of dealing.

There is, however, no general duty to deal in U.S. law, and the Supreme Court has noted that such a duty is in tension with antitrust policy. ${ }^{199}$ In Trinko, the Supreme Court found no duty to supply its proprietary infrastructure, as the accused company had never voluntarily shared it with its competitors. ${ }^{200}$ The Supreme Court noted that they have been 'very cautious in recognizing [a duty to deal], because of the uncertain virtue of forced sharing and the difficulty of identifying and remedying anticompetitive conduct by a single firm. ${ }^{201}$ The Federal Circuit has held that patentees have a presumptive right to refuse to sell or license in the absence of illegal tying, fraud in the Patent and Trademark Office, or sham litigation. ${ }^{202}$ The antitrust agencies have also recognized that refusal to assist competitors does not generally trigger liability partly because of the risk of undermining incentives to innovate. ${ }^{203}$ The essential facilities doctrine is considered inconsistent with IP protection.

The courts have ordered patentees to license on F/RAND-like terms as remedies for anti-competitive conduct fairly frequently since the $1940 \mathrm{~s} .{ }^{204}$ For instance in 1947 United States v. National Lead, the courts found a patent pooling arrangement to violate Section 1,205 and the District Court ordered the defendants to 'grant to any applicant ... a non-exclusive license under any or all of the patents ... at a uniform, reasonable royalty. ${ }^{206}$ Although the number of remedial patent licensing orders has declined since the 1970s, they have remained relevant especially with regard to merger review. ${ }^{207}$ For instance in 1997, Cadence Design Systems agreed to settle the FTC charges that its acquisition of Cooper \& Chyan Technology would substantially reduce competition in the market for automated chip design routing software. ${ }^{208}$ According to the FTC, Cadence was a dominant supplier of chip layout environments, and CCT the only company with a commercially viable constraint-driven, shape-based routing tool. ${ }^{209}$ The FTC found that the merger would reduce the incentives of Cadence to allow competing suppliers of routing tools access to its software interface programs, which in turn would hinder routing tool developers' entry into the market. ${ }^{210}$ As a remedy, the consent order required Cadence to allow software developers of routing tools to participate in its software interface programs on a non-discriminatory basis. ${ }^{211}$

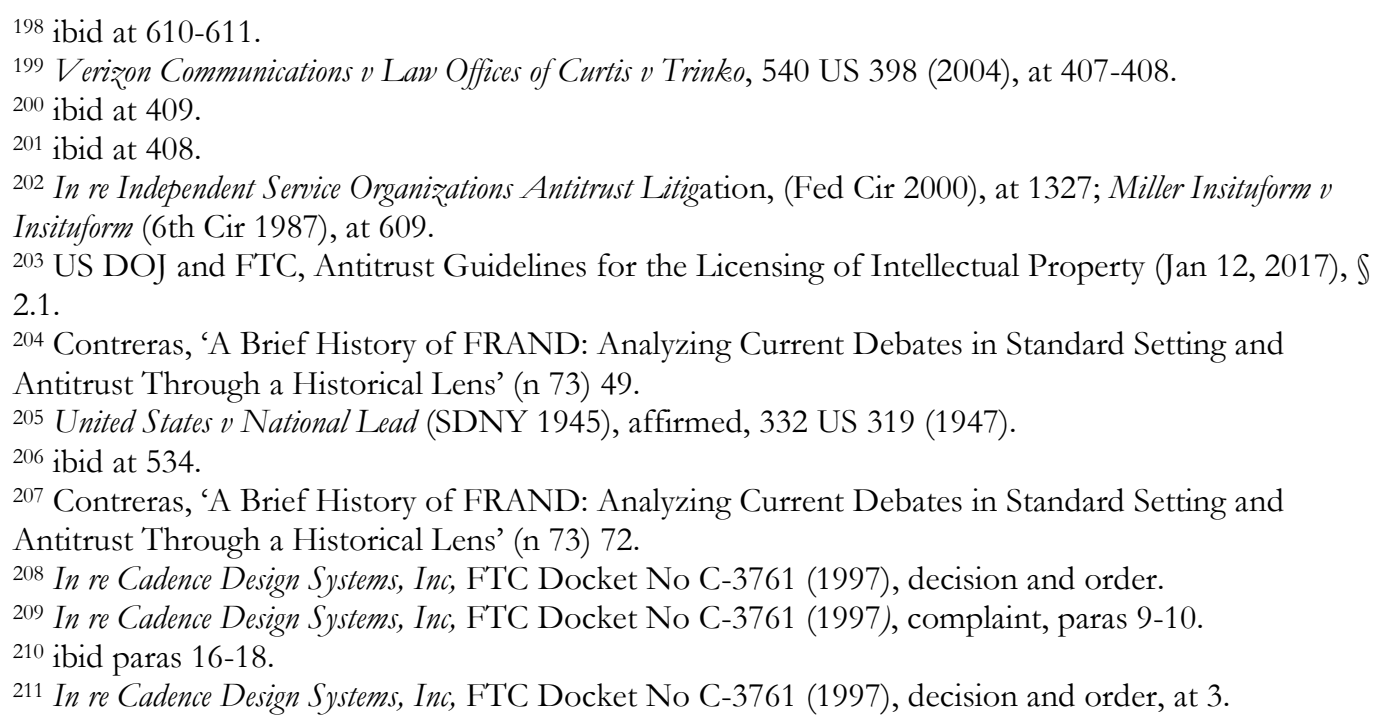




\section{4. [b] Duty to Deal in EU Law}

The European Commission stresses that every company, even a dominant one, should have the right to choose its partners to contract with, and that mandatory supplying may compromise incentives to innovate and ultimately harm consumers. ${ }^{212}$ Yet a refusal to deal has been found to be abuse of dominance on several occasions.

The CJEU has established that a dominant undertaking may violate Article 102 of the TFEU by terminating supplies to a long-standing customer. ${ }^{213}$ What is more, a duty to license was seemingly introduced in Magill, ${ }^{214}$ where broadcasters held factual and legal monopoly over their television program listings, which they had not shared with others. The Commission found abuse of a dominant position in the broadcasters refusing to license the copyrighted material to a third party who wished to create a new product. ${ }^{215}$ The broadcasters replied with an argument that an IPR owner's refusal to license forms part of the specific subject matter of that exclusive right and thus it is justified. ${ }^{216}$ Nevertheless, the CJEU held that a dominant undertaking's refusal to license may constitute abuse in exceptional circumstances. ${ }^{217}$ In Magill, the exceptional circumstances were found to exist as the broadcasters' refusal to provide information effectively prevented the creation of a new product in a secondary market, namely a comprehensive weekly television programme guide, for which there was a potential consumer demand. ${ }^{218}$ An obligation to license on F/RAND-like terms was imposed as a remedy. ${ }^{219}$ The CJEU thus suggested that indispensability, the legal impossibility of replicating, is a ground for competition law interference in rights to exclude.

A few years later in Oscar Bronner, ${ }^{220}$ the CJEU clarified the test of indispensability. The CJEU specified that there must be no potential realistic substitute by reason of technical, legal, or economic obstacles capable of making it impossible or unreasonably difficult for an undertaking to replicate on its own or in cooperation with other undertakings. ${ }^{221}$ However, it is not sufficient that a substitute is merely less advantageous. ${ }^{222}$ The CJEU expanded the duty to license in its later case law. In IMS Health, ${ }^{223}$ IMS provided German regional sales data on drug products through its copyrighted grid which divided the territory of Germany into 1,860 areas or bricks (the

\footnotetext{
212 Commission Communication, Guidance on the Commission's enforcement priorities in applying Article [102 TFEU] to abusive exclusionary conduct by dominant undertakings [2009] OJ C45/02, para 75.

${ }^{213}$ Cases 6 and 7/73 Istituto Chemioterapico Italiano SpA and CommercialSolvents Corporation [1974], para 25; Case 27/76 United Brands [1978], para 182.

${ }^{214}$ Cases C-241/91 P and C-242/91 P RTE and ITP (Magill), [1995].

${ }^{215}$ Magill TV Guide/ITP, BBC \& RTE (Case IV/31.851) Commission Decision 89/205/EEC [1989]

OJ L 78/43.

${ }^{216}$ Cases C-241/91 P and C-242/91 P RTE and ITP (Magill), [1995], para 40.

217 ibid para 50.

218 ibid para 54.

${ }^{219}$ Magill TV Guide/ITP, BBC \& RTE (Case IV/31.851) Commission Decision 89/205/EEC [1989]

OJ L $78 / 43$.

${ }^{220}$ Case C-7/97, Oscar Bronner v Mediaprint, [1998].

221 ibid paras 41-45.

222 ibid para 43.

${ }^{223}$ Case C-418/01 IMS Health v NDC Health [2004].
} 

'1860 brick structure') to pharmaceutical companies who then organized their supplies based on that structure. Consequently, the 1860 brick structure became a de facto industry standard. NDC, an undertaking wishing to entry into the market, adopted the structure because of the fact that customers rejected the alternative structures introduced by NDC, and IMS subsequently sued for an infringement. The CJEU found an abusive refusal to license, noting that indispensability included situations in which replication is 'not economically viable for production on a scale comparable to that of the undertaking which controls the existing product or service. ${ }^{, 24}$ The CJEU also diluted the requirement that the refusal must be likely to exclude all competition in the secondary market by holding that it is sufficient to find the effect in relation to a potential or even a hypothetical market. ${ }^{225}$ Furthermore, the CJEU did not focus on the fact that there was no obvious new product involved in the case.

The law on the duty to deal was changed radically in Microsoft. ${ }^{226}$ In Microsoft, the Commission deemed that Windows had become a de facto industry standard in the market for client PC operating systems, ${ }^{227}$ and Microsoft had abused its dominant position by refusing to disclose (partly patented) interoperability information with its Windows operating system, which was an essential facility for companies in computer and software industries. According to the Commission, the refusal to disclose impeded market entry. ${ }^{228}$ The Commission found that in order to compete viably in the market for work group server operating systems, such a system must be able to communicate with Microsoft's Windows client PC operating system 'on an equal footing with Windows work group server operating systems. ${ }^{229}$ Surprisingly enough, the Commission literally equated viability with the ability of the dominant undertaking. The General Court reformed the earlier case law and stated that a refusal to license constitutes abuse absent objective justification where, in addition to the previously established requirements, effective competition (and not all) in the secondary market is excluded. ${ }^{230}$ Basically, a refusal to license may amount to a violation if it might eliminate a competitive constraint or prevent the development of a new one in a possible secondary market. ${ }^{231}$ Another troublesome reform concerns the new product -test. Microsoft argued that the Commission failed to identify any new product of which emergence would be prevented by the refusal to supply and merely claims that Microsoft's competitors 'could use the disclosures to [develop] the advanced features of their own products. ${ }^{232}$ The Commission had replied that for a product to be new, it is sufficient for a product to contain substantial elements contributed by the licensee's own efforts. ${ }^{, 233}$ The General Court confirmed that it is not necessary that a refusal to license prevents the emergence of a new product - it suffices that there is a

\footnotetext{
224 ibid para 28.

225 ibid para 44.

226 Case T-201/04 Microsoft [2007].

227 ibid paras 31-32.

228 ibid para 33.

229 ibid para 230.

230 ibid para 332.

${ }^{231}$ Devlin (n 3) 153.

232 Case T-201/04 Microsoft [2007], para 624.

233 ibid para 626.
} 
limitation of technical development. ${ }^{234}$ Naturally, Microsoft aimed to justify its refusal by the argument that the requested technology was covered by IPRs and that a duty to disclose would eliminate future incentives to invest in innovation. ${ }^{235}$ The General Court, however, rejected that argument by simply holding that it lacked proof. ${ }^{236}$ That holding is a defeat for patentees trying to justify their right to exclude. Nevertheless, Microsoft had disclosed interoperability information to third parties before, which arguably affected the CJEU's decision to reject Microsoft's justification. ${ }^{237}$

\section{CASE LAW ON THE ND PRONG}

Few court decisions have provided an analysis on the meaning and implications of the ND prong of F/RAND, and no uniform definition exists. The decisions provide only evolving ideas as they are bound to the particular facts of the cases in an immature field of law. These ideas are distilled mainly from U.S. court decisions, as the courts in Europe have largely refrained from addressing disputes over the meaning of the ND prong. The disputes have concerned patent infringement damages, breaches of contract, and antitrust violations. This chapter examines the case law development on the ND prong in a chronological order, albeit no comprehensive summary of relevant cases is sought to be provided.

The first section discusses the landmark case Georgia-Pacific and the established framework for the determination of royalties that has been widely employed in later case law. The second section examines Judge Robart's decision in Microsoft v. Motorola, which was the first time a U.S. court determined RAND royalties for a SEP license. Judge Holderman's decision in Innovatio is examined in the third section, which offers a very different approach to determining RAND royalties than the one Judge Robart had. The fourth section discusses Justice Briss' decision in Unwired Planet v. Huawei in the United Kingdom, which provides a rather detailed analysis on the ND prong specifically. Lastly, the fifth section analyses Judge Selna's recently published decision in TCL $v$. Ericsson, which presents another detailed analysis on the ND prong.

\subsection{GEORGIA-PACIFIC}

The U.S. District Court came up with a seminal method for calculation of reasonable royalty damages for patent infringements in the landmark case Georgia-Pacific in 1970. ${ }^{238}$ The method simulates a hypothetical negotiation between a willing licensor and a willing licensee, which is assumed to take place when the infringement began. Although the decision addresses patent infringement damages and not F/RAND terms, the method has been employed by the courts in F/RAND disputes.

\footnotetext{
234 ibid para 647.

235 ibid para 689.

236 ibid para 697.

${ }^{237}$ Case T-201/04 Microsoft [2007], para 702.

238 Georgia-Pacific Corp v United States Plywood Corp, 318 F Supp 1116 (SDNY 1970), modified and affirmed, 446 F2d 295 (2d Cir 1971), certiorari denied, 404 US 870 (1971).
} 
The method provides the following 15 factors to be considered when determining reasonable royalties: (1) Royalties received by the patentee for licensing the patent in suit; (2) Rates paid by the licensee for use of other patents comparable to the patent in suit; (3) Nature and scope of the license in terms of exclusivity and territory or customer restrictions; (4) The licensor's established policy and marketing program to maintain patent monopoly by not licensing to others to use the invention or by granting licenses under special conditions designed to preserve that monopoly; (5) Commercial relationship between the licensor and the licensee, such as whether they are competitors or an inventor and a promoter; (6) Effect of selling the patented specialty in promoting sales of other products of the licensee; the existing value of the invention to the licensor as a generator of sales of non-patented items; and the extent of such derivative or convoyed sales; (7) Duration of the patent and the term of the license; (8) Established profitability of the products made under the patent, its commercial success and its current popularity; (9) Utility and advantages of the patent property over old modes and devices that had been used for similar results; (10) The nature of the patented invention; the character of the commercial embodiment of it as owned and produced by the licensor; and the benefit of those who have used the invention; (11) The extent to which the infringer has made use of the invention and the value of such use; (12) The portion of profit or selling price customarily allowed for the use of the invention or analogous inventions; (13) The portion of realizable profit attributable to the invention as distinguished from non-patented elements, significant features or improvements added by the infringer, the manufacturing process, business risks, or significant features or improvements added by the infringer; (14) Opinion testimony of qualified experts; and (15) Outcome of a hypothetical arm's length negotiation between a prudent licensor and a licensee. ${ }^{239}$

Rulings in patent infringement cases and the Georgia-Pacific factors may provide a useful framework for the determination of F/RAND royalties. ${ }^{240}$ Often in patent infringement cases, reasonable royalty damages reflect the royalty that would have been negotiated before the potential licensee implemented the patented technology, which is based on the value of the patented technology over the next-best alternatives. ${ }^{241}$ Price discrimination is legitimate to the extent that the patented technology is more valuable to one implementer than to another. In the standard setting context, the idea is that license terms should reflect terms which the SEP holder would have committed to before the standard was set, considering possible alternative technologies that existed before companies sunk investments into implementing the standard. ${ }^{242}$ One of the approaches to determine $\mathrm{F} / \mathrm{RAND}$ royalties is to measure the ex ante incremental value of the SEP relative to its alternative technologies (the so-called 'bottom-up approach'), ${ }^{243}$ according to which the monetary value of the SEP technology, namely the value derived from advantages in performance and cost-savings, is calculated. ${ }^{244}$

\footnotetext{
${ }^{239}$ Georgia-Pacific Corp v United States Plywood Corp, 318 F Supp 1116 (SDNY 1970), at 1119-20.

240 Brooks and Geradin (n 61) 25; Pentheroudakis and Baron (n 32) 61.

${ }^{241}$ Carlton and Shampine (n 40) 536.

242 ibid 541; Mariniello (n 34) 526.

${ }^{243}$ Leonard and Lopez (n 84) 88.

244 ibid 89.
} 

However, it may be extremely burdensome to apply in practice. ${ }^{245}$ The Georgia-Pacific framework allows taking into account information in addition to mathematical formulae, such as comparable licenses. The Georgia-Pacific framework has been referred to in F/RAND cases, although in an altered form.

\subsection{MICROSOFT V. MOTOROLA}

District Court Judge James L. Robart issued a decision on 25 April 2013 on a breach of contract case between Microsoft and Motorola, which was the first time a U.S. court determined RAND royalty rates, or a royalty range, ${ }^{246}$ for a license for SEPs. Judge Robart analyzed whether Motorola had breached its RAND commitments in offering a license for its patents essential to ITU's video coding and IEEE's Wi-Fi standards.

Judge Robart specified that Motorola's RAND commitments require Motorola to make initial offers to license its SEPs in good faith, and that those offers do not need to be on RAND terms so long as the ultimate resulting license is. ${ }^{247}$ In order to decide whether Motorola's initial royalty offers were in good faith, Judge Robart sought to determine a RAND royalty range, because 'more than one rate could conceivably be RAND. ${ }^{248}$ Judge Robart reasoned that RAND royalties would be best determined by resorting to a hypothetical negotiation involving RAND commitments. ${ }^{249} \mathrm{He}$ applied an altered Georgia-Pacific framework, noting that not all 15 Georgia-Pacific factors are applicable in a RAND situation. ${ }^{250}$ Among other changes, he held that factors four and five of the Georgia-Pacific framework are inapplicable in the RAND context as a SEP holder committed to license on RAND terms is obliged to grant a license on RAND terms to all implementers of the standard and may not discriminate even against its competitors. ${ }^{251}$ Central to the analysis was to consider 'the importance of the SEPs to the standard and the importance of the standard and the SEPs to the products at issue. ${ }^{252}$ Judge Robart emphasized the importance of factors six and eight that allow considering the incremental value of the SEP technology to the implementer and its products. ${ }^{253}$ The value to the licensee created by the standard itself would not be taken into account in RAND royalties. ${ }^{254}$ RAND-committed SEP holders may set differential royalties based on the importance of the SEP's technology to the products at issue. In determining RAND royalty rates, Judge Robart relied mainly on comparable licenses.

A SEP holder may also commit an antitrust offense by favouring some implementers over others. The Third Circuit held in Broadcom v. Qualcomm that a company's 'deceptive FRAND commitment to [a standard setting organization] may

\footnotetext{
${ }^{245}$ Microsoft v Motorola, (WD Wash Apr 25, 2013), para 77.

246 ibid at 5.

247 ibid.

248 ibid.

249 ibid at 7.

250 ibid para 99.

251 ibid paras 101-102.

252 ibid at 7.

253 ibid paras 103-104.

254 ibid para 104.
} 
constitute actionable anticompetitive conduct. ${ }^{255}$ Qualcomm had violated its FRAND commitment and discriminated in its SEP licensing practices by charging more and higher fees to licensees who did not use Qualcomm's UMTS chipsets and by providing discounts to those who used only Qualcomm's UMTS chipsets, and attempted to obtain a monopoly in the UMTS chipset market in violation of antitrust law. ${ }^{256}$

\subsection{IN RE INNOVATIO}

On 27 September 2013, District Court Judge James Holderman determined RAND royalties for Innovatio's portfolio of patents essential to IEEE's Wi-Fi telecommunications standard as damages in a patent infringement case between Innovatio and some wireless network users. He generally followed the Georgia-Pacific framework modified by Judge Robart in Microsoft v. Motorola. ${ }^{257}$ However, it has been held by the courts that the framework is not always necessary. ${ }^{258}$ Although Judge Holderman recognized the importance of considering the value of 'the patent portfolio as a whole to the alleged infringer's accused products, ${ }^{259}$ he set RAND royalties differently than Judge Robart in Microsoft v. Motorola. He held that Innovatio should charge the end-product manufacturers for the use of the portfolio of SEPs the same amount of royalties as it would charge to chip manufacturers for those patents, regardless of differences in the devices. ${ }^{260}$

Judge Holderman opined that 'the Top Down approach best approximates the RAND rate that the parties to a hypothetical ex ante negotiation most likely would have agreed upon, ${ }^{261}$ and relied on that approach in the absence of apparent comparable licenses. ${ }^{262}$ According to the top-down approach, first the aggregate royalty burden that could be charged for all SEPs relevant to the standard is determined, after which the aggregate royalty burden is divided among the SEPs by considering their relative value. ${ }^{263}$ The royalty for the infringed patents were to be calculated on the SSPPU. ${ }^{264}$ The courts have held that in patent infringement cases, royalties may be based on the entire market value of the multi-component product only if the patented technology drives demand for the whole product (the so-called Entire Market Value -rule) ${ }^{265}$ If that cannot be established, the patentee must somehow apportion the value contributed by the technology to the product. ${ }^{266}$ Judge Holderman found that the SSPPU was a Wi-Fi chip that provides the device with Wi-Fi functionality, and assessed

\footnotetext{
255 Broadcom v Qualcomm, (3d Cir 2007), at 315.

256 ibid at 318.

${ }^{257}$ In re Innovatio IP Ventures, (ND Ill, Sep 27, 2013), at 8-11.

258 Ericsson v D-Link Sys, (Fed Cir 2014), at 1231.

${ }^{259}$ In re Innovatio IP Ventures, (ND Ill, Sep 27, 2013), at 10.

260 ibid at 13.

261 ibid at 73 .

$262 \mathrm{ibid}$ at 72 .

${ }^{263}$ Leonard and Lopez (n 84) 89; Contreras, 'Global Markets, Competition, and FRAND Royalties:

The Many Implications of Unwired Planet v Huawei’ (n 61) 10.

${ }^{264}$ In re Innovatio IP Ventures, (ND Ill, Sep 27, 2013), at 23.

${ }^{265}$ Ericsson v D-Link (Fed Cir 2014), at 1227; LaserDynamics v Quanta Computer, 694 F3d 51 (Fed Cir

2012), at 67.

266 Ericsson v D-Link (Fed Cir 2014), at 1226.
} 
the royalty based on the profit margin on the sale of a Wi-Fi chip. ${ }^{267}$ The approach begins with the average price of a Wi-Fi chip, based on which the average profit to a chipmaker on the sale of each chip is determined. ${ }^{268}$ The profit on a chip is then multiplied by a fraction calculated as the number of Innovatio's relevant SEPs, and finally divided by the total number of the relevant SEPs. ${ }^{269}$ Judge Holderman emphasized that the methodology is suitable because a RAND-committed patentee 'cannot discriminate between licensees on the basis of their position in the market. ${ }^{270}$

Judge Holderman rejected Innvovatio's suggested method of using the profit margins of the manufacturers on their end-products with Wi-Fi functionality (such as laptops, tablets, printers and access points) as the royalty base, ${ }^{271}$ adjusted to the value of the devices that is attributable to the 'Wi-Fi feature factor. ${ }^{272}$ Innovatio proposed that the Wi-Fi feature factor percentage varies between different types of endproducts: whereas a laptop has a feature factor of 10 per cent reflecting that only 10 per cent of its value is due to $\mathrm{Wi}-\mathrm{Fi}$, an access point has a feature factor of 95 per cent reflecting that almost all of its value is due to $\mathrm{Wi}_{-}-\mathrm{Fi}^{273}$ The rejection was due to the fact that Innovatio failed to apportion the value of the devices down to the patented features credibly. ${ }^{274}$

The decision raises the question whether the ND prong of F/RAND allows differential royalties to be charged based on different types of devices. The difference in the approaches to the non-discrimination requirement in Innovatio and Microsoft $v$. Motorola may be, however, due to the facts of the cases and available evidence rather than different legal interpretations. Furthermore, in Innovatio, the subject of litigation was the precise amount of patent infringement damages whereas Microsoft v. Motorola concerned license terms offered in bilateral negotiations. The SSPPU rule seems to be designed to function as an evidentiary tool primarily for patent infringement jury trials. ${ }^{275}$ It is not the definitive rule for determining royalties in all contexts.

\subsection{UNWIRED PLANET V. HUAWEI}

On 5 April 2017, Mr. Justice Colin Briss of the High Court of Justice of England and Wales decided on Unwired Planet's offers to license its patents essential to ETSI's 3G and 4G standards to Huawei and their compatibility with Unwired Planet's FRAND commitment. ${ }^{276}$ He viewed the dispute mainly through the competition law lens. ${ }^{277}$ In the lack of previous case law on the exact definition of the ND prong of F/RAND, Justice Briss' analysis has a significant bearing.

267 In re Innovatio IP Ventures, (ND Ill, Sep 27, 2013), at 34, 74, 76.

268 ibid at 73-74.

$269 \mathrm{ibid}$ at 74 .

270 ibid.

271 ibid at 21-22.

272 ibid at 22 .

273 ibid.

274 ibid at 26-27.

275 (n 89).

276 Unwired Planet v Huawei [2017] EWHC 711 (Pat) (Apr 5, 2017).

277 Contreras, 'Global Markets, Competition, and FRAND Royalties: The Many Implications of Unwired Planet v Huawei' (n 61) 1. 

Deviating from the approach developed in Microsoft v. Motorola, Justice Briss reasoned that, legally speaking, there is but a single FRAND royalty rate for any given set of SEPs and devices. ${ }^{278}$ However, parties to negotiations over SEP licenses may agree on any royalty rate within the limits of competition law. ${ }^{279}$ SEP holders may make initial offers higher than FRAND in negotiations without violating competition law unless the offer is so far above FRAND as to act to disrupt or prejudice the negotiations themselves. ${ }^{280}$ Justice Briss thus seemingly loosened the procedural obligation set by the CJEU in Huawei v. ZTE that a SEP holder's initial license offer to an implementer must be FRAND in order to avoid a breach of Article 102 of the TFEU. ${ }^{281}$ Justice Briss noted that a SEP holder would end up with negotiated royalty rated below FRAND if the initial offer was actually FRAND. ${ }^{282}$ Nevertheless, the end result seems to be same with the two approaches, namely with the approach of fixing a single rate with a margin of error and the approach of fixing a royalty range. ${ }^{283}$ However, no guidance is given on the margin of error by which the negotiated royalty rate that is allegedly above the single FRAND rate results in a penalty. ${ }^{284}$

Justice Briss offered two possible methods for calculating a benchmark FRAND royalty rate: an analysis of comparable royalty rates, and the top-down analysis. ${ }^{285}$ Comparable transactions such as existing licenses covering the SEPs in question can be used as benchmarks for the SEP's value in order to ascertain the market's valuation of the SEPs at hand or comparable technologies. ${ }^{286}$ Comparable licenses may indicate a likely outcome of hypothetical ex ante negotiations. ${ }^{287}$ Justice Briss relied mainly on the method of benchmarking against comparable licenses, such as licenses that Unwired Planet had previously granted for those SEPs. Surprisingly enough, he departed from two yardsticks employed by the U.S. courts. ${ }^{288}$ First, he rejected the idea that a FRAND royalty rate should reflect the ex ante value of the patented technology, and thus departed from Innovatio. ${ }^{289}$ Second, he made no reference to the Georgia-Pacific factors which the U.S. courts tend to apply to determine FRAND royalties. ${ }^{290}$

Justice Briss examined the proposed definitions of the ND prong of FRAND and relied on the definition that SEP holders should treat 'similarly situated licensees similarly. ${ }^{291}$ Unwired Planet and Huawei agreed that the ND prong has the same meaning as the prohibition of discrimination under Article 102(c) of the TFEU. ${ }^{292}$

278 Unwired Planet v Huawei [2017] EWHC 711 (Pat) (Apr 5, 2017), paras 156, 164.

279 ibid para 155.

280 ibid para 765.

281 Case C-170/13 Huawei Technologies v ZTE, EU:C:2015:477, paras 63-64.

282 Unwired Planet v Huawei [2017] EWHC 711 (Pat) (Apr 5, 2017), para 159.

${ }^{283}$ Contreras, 'Global Markets, Competition, and FRAND Royalties: The Many Implications of Unwired Planet v Huawei’ (n 61) 4.

284 ibid 3.

285 Unwired Planet v Huawei [2017] EWHC 711 (Pat) (Apr 5, 2017), paras 178, 179.

${ }^{286}$ Leonard and Lopez (n 84) 91.

287 Pentheroudakis and Baron (n 32) 147.

${ }^{288}$ Contreras, 'Global Markets, Competition, and FRAND Royalties: The Many Implications of Unwired Planet v Huawei' (n 61) 8.

289 Unwired Planet v Huawei [2017] EWHC 711 (Pat) (Apr 5, 2017), para 97.

${ }^{290}$ Contreras, 'Global Markets, Competition, and FRAND Royalties: The Many Implications of Unwired Planet v Huawei’ (n 61) 8.

291 Unwired Planet v Huawei [2017] EWHC 711 (Pat) (Apr 5, 2017), para 485.

292 ibid para 487. 
Article 102(c) prohibits dissimilar conditions when (a) they are applied to equivalent or comparable transactions; (b) they result in actual or potential distortion of competition; and (c) there is no objective justification. ${ }^{293}$ Transactions are comparable if '(a) they are concluded with purchasers who compete with one another, or who produce the same or similar goods, or who carry out similar functions in distribution, (b) they involve the same or similar products, (c) in addition their other relevant commercial features do not essentially differ. ${ }^{, 294}$ However, the parties' interpretations of treating similarly situated licensees similarly differed: Huawei proposed that the nondiscrimination obligation requires the same or similar rates to similarly situated licensees, whereas Unwired Planet proposed that only differences that are capable of distorting competition are prohibited. ${ }^{295}$ Justice Briss rejected Huawei's interpretation, observing that competition law prohibiting discriminatory pricing operates to achieve a fair balance, which a blanket prohibition would not do. ${ }^{296}$ The ND prong does not introduce a 'hard-edged' non-discrimination obligation. ${ }^{297}$ Justice Briss emphasized that the ND prong only requires the establishment of a benchmark royalty rate that is applicable to all licensees seeking the same kind of a license. ${ }^{298}$ Furthermore, a FRAND royalty should not be based on the size, bargaining power, or other characteristics of the licensee. ${ }^{299}$

\subsection{TCL V. ERICSSON}

On 8 November 2017, the decision of Judge James V. Selna of the Central District of California on the long-standing dispute between TCL and Ericsson arising under licenses for Ericsson's portfolio of patents essential to ETSI's 2G, 3G, and 4G standards was rendered. Judge Selna evaluated whether Ericsson's license offers were compatible with its FRAND commitments. In an earlier case in August 2016, Judge Selna had ruled that TCL had not established an antitrust claim due to the lack of evidence of Ericsson making 'an intentionally false promise' to the SSO ${ }^{300}$ Antitrust law claim requires bad intent in violation of the policy or spirit of antitrust law in addition to a breach of the F/RAND obligation. ${ }^{301}$ The decision of 2017 provides a detailed analysis on the ND prong of FRAND.

Judge Selna determined FRAND royalty rates by first employing the top-down method and then cross-checking them against comparable licenses, using the methods in reverse order than Justice Briss in Uniwired Planet. Royalties were calculated based on the end-products, and the possibility of applying the SSPPU was not addressed. Furthermore, the court 'did not find useful a full-blown Georgia-Pacific analysis in the

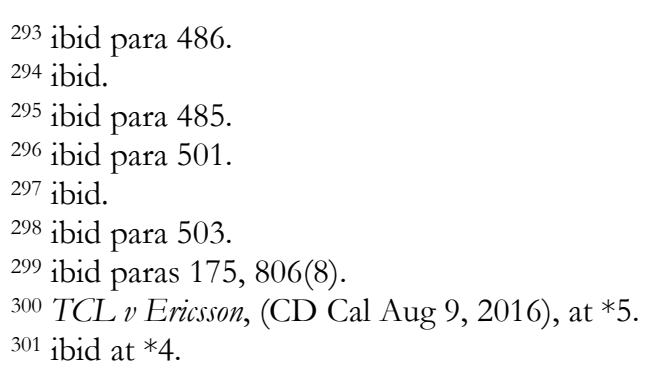


unique context of a FRAND dispute. ${ }^{302}$ Six companies were identified that license the same SEPs from Ericsson and appeared to be similarly situated to TCL. ${ }^{303}$

The parties agreed that 'like, or close to like, rates must be offered to firms which are similarly situated. ${ }^{304}$ Judge Selna recognized that the parties' experts tend to consider similarly situated companies as 'companies using the same technology and at a similar level in the value chain. ${ }^{305} \mathrm{He}$ advocated a broad interpretation of 'similarly situated' because of the dynamic nature of the mobile phone market. ${ }^{306}$ In addition to considering whether the companies manufacture similar devices, Judge Selna considered some relevant factors in determining which companies are similarly situated to be the geographic scope of the licensee's business, the scope of the required license, and sales volume. ${ }^{307} \mathrm{He}$ found the geographic scope to be the most important factor in the case at hand. ${ }^{308} \mathrm{He}$ rejected Ericsson's suggestion that factors such as the licensee's overall financial success or risk, brand recognition, device operating system, or retail stores would be relevant. ${ }^{309}$ Furthermore, he specified that '[s]ales volume alone does not justify giving lower rates to otherwise similar firms,' but it is used as a filter to separate small companies from reasonably well-established global ones like TCL. ${ }^{310}$ According to Judge Selna, the non-discrimination obligation does not require the offered royalty rate to be the same as the lowest one offered to other implementers in the market. ${ }^{311}$ There is no single FRAND royalty rate, but the rates charged to different licensees may vary depending on the 'economics of the specific license. ${ }^{312}$

Judge Selna made an important observation that royalty rates may be found discriminatory and in breach of a FRAND commitment without proof of distortion of competition in the market so long as the competitor company has been harmed. ${ }^{313}$ In antitrust law, harm to competition is actionable whereas mere harm to a competitor is not. ${ }^{314}$ ETSI's and other SSOs' non-discrimination obligations of FRAND commitments do not necessarily require impairment of competition as a whole. ${ }^{315}$ The concept of discrimination in the context of FRAND commitments required by SSOs differs from the concept of price discrimination in antitrust law.

\footnotetext{
302 TCL $v$ Ericsson, (CD Cal Dec 21, 2017), at 110.

303 ibid at 58 .

304 ibid at 54 .

$305 \mathrm{ibid}$ at 57 .

306 ibid.

307 ibid at 58 .

$308 \mathrm{ibid}$ at 59 .

$309 \mathrm{ibid}$ at 58 .

310 ibid at 61 .

311 ibid at 109.

312 ibid.

313 ibid at 91 .

314 ibid.

315 ibid.
} 


\section{PROPOSED FRAMEWORK ON CHARGING DIFFERENTIAL ROYALTIES}

This chapter proposes a framework for answering the question: 'To what extent is a F/RAND-committed SEP holder legally allowed to charge differential royalties to different licensees for the patented technology from the U.S. and the EU perspectives?' The analytical starting point is that a SEP holder's freedom to license its patented technology is limited in order to prevent the risk of patent hold-up or, in other words, abuse of market power flowing from the essentiality of the standard. The objective of the ND prong of F/RAND commitments imposed by SSOs such as IEEE, JEDEC, and ETSI is to ensure that SEPs are available to all implementers. Thus, F/RANDcommitted patentees' right to exclude others from using the patented technology is waived to some extent. The logic is similar to antitrust compulsory licensing: for the sake of follow-on innovation, SEP holders cannot refuse to license. IEEE, JEDEC, and ETSI's bylaws do not provide a detailed definition of the ND prong, but they clearly allow SEP holders to charge differential license terms to different licensees. The court decisions in Microsoft v. Motorola, Innovatio, Unwired Planet v. Huawei, and TCL v. Ericsson as well as the interpretations and normative arguments of commentators provide useful ideas on SEP holders' capability to set differential royalties. However, as already mentioned in the previous chapter, the court decisions provide no definitive all-encompassing answers as they are bound to the specific facts of the cases in a rather new, still evolving field of law. Moreover, decisions of lower courts are not binding on higher courts in the specific system, or on other jurisdictions. Be that as it may, considering the limited amount of court decisions, these decisions surely have an impact on companies' licensing strategies.

The ND prong limits SEP holders' ability to set differential license terms to different licensees. The first section analyses the legal possibility of F/RANDcommitted SEP holders to set differential royalties based on the nature of licensees' devices incorporating the patented technology, and the second section examines the degree of flexibility to set license terms to licensees manufacturing similar devices.

\subsection{DIFFERENTIAL ROYALTIES BASED ON THE NATURE OF DEVICES}

It seems to be possible for F/RAND-committed SEP holders to charge differential royalties based on the nature of licensees' devices incorporating the patented technology lawfully. Royalty rates may be based on the value of the patented technology to the licensee and its device relative to alternative technologies ex ante. ${ }^{316}$ The incremental value derived from the inclusion of the technology into a standard should not be taken into account, ${ }^{317}$ although this assertion has been disputed. ${ }^{318}$ There are multiple methods to establish the value of the technology, such as the bottom-up and top-down approaches and the use of comparable licenses. ${ }^{319}$

\footnotetext{
316 Microsoft v Motorola, (WD Wash Apr 25, 2013).

317 ibid para 104.

318 Unwired Planet v Huawei [2017] EWHC 711, para 97.

${ }^{319}$ Leonard and Lopez (n 84) 88-92.
} 
The ND prong of F/RAND is commonly interpreted as a requirement to license to similarly situated licensees on similar terms, ${ }^{320}$ and there appears to be consensus that licensees implementing the technology in dissimilar devices and competing in different product markets or industries are not similarly situated. ${ }^{321} \mathrm{~J}$. Gregory Sidak has found this assertion to be 'economically sound' as 'manufacturers of different products typically derive different values from implementing a given industry standard. ${ }^{322}$ Commentators such as Dennis Carlton, Allan Shampine, and Anne LayneFarrar have interpreted licensees expecting to derive the same value from the patented technology (ex ante) to be similarly situated, ${ }^{323}$ and licensees manufacturing similar devices and using the same production technology are likely to obtain the same value. ${ }^{324}$ The parties in Unwired Planet $v$. Huawei considered a similar situation to mean the involvement of equivalent or comparable transactions as in the prohibition of discrimination under Article 102(c) of the TFEU, which largely correlates to Section 2(a) of the Robinson-Patman Act. ${ }^{325}$ In relation to Article 102(c) of the TFEU, transactions may be comparable if, inter alia, they are concluded with purchasers competing in the same product market. ${ }^{326}$ Similarly, Section 2(a) of the RobinsonPatman Act prohibits price discrimination injuring competition between the seller's customers, thus referring to customers active on the same product market. The parties in TCL v. Ericsson suggested that similarly situated licensees means those 'using the same technology and at a similar level in the value chain, ${ }^{327}$ which also points to licensees manufacturing similar devices.

F/RAND-committed SEP holders have the legal possibility to set differential royalties based on the nature of licensees' devices. However, when it is practically difficult to apportion the value that the implementers and their devices derive from the patented technology essential to the standard, courts have fixed a royalty rate based on a 'common component' incorporating the patented technology, which may reflect the SSPPU. ${ }^{328}$ Thus, the definition of similarly situated licensees is flexible for practical purposes.

\footnotetext{
${ }^{320}$ TCL $v$ Ericsson, (CD Cal Dec 21, 2017), at 54, 57; Unwired Planet v Huawei [2017] EWHC 711, para 485; Layne-Farrar (n 53) 815; Gilbert (n 16) 858; Carlton and Shampine (n 40) 546-547; Sidak, 'The Meaning of FRAND, Part I: Royalties' (n 28) 996-997.

${ }^{321}$ Contreras, 'A Brief History of FRAND: Analyzing Current Debates in Standard Setting and Antitrust Through a Historical Lens' (n 73) 79; Sidak, 'Fair and Unfair Discrimination in Royalties for Standard-Essential Patents Encumbered by a FRAND or RAND Commitment' (n 59) 356.

322 Sidak, 'Fair and Unfair Discrimination in Royalties for Standard-Essential Patents Encumbered by a FRAND or RAND Commitment' (n 59) 359-360.

${ }^{323}$ Layne-Farrar (n 53) 815; Carlton and Shampine (n 40) 546.

324 Carlton and Shampine (n 40) 547.

325 Unwired Planet v Huawei [2017] EWHC 711, para 486.

326 ibid.

327 TCL $v$ Ericsson, (CD Cal Dec 21, 2017), at 57.

328 See, for instance, In re Innovatio IP Ventures, (ND Ill, Sep 27, 2013).
} 


\subsection{DIFFERENTIAL ROYALTIES TO LICENSEES MANUFACTURING SIMILAR DEVICES}

F/RAND-committed SEP holders must not discriminate between licensees based on their position in the market, ${ }^{329}$ and they are obliged to license similarly situated licensees on similar terms. Some degree of flexibility to negotiate and set license terms is implied. The court decisions and the interpretations of commentators support the view that there exists no single unique F/RAND royalty rate for specific SEPs and devices but a F/RAND range. ${ }^{330}$ Furthermore, as mentioned in the first section of this chapter, there are many potential methods to determine royalties and thus the boundaries of a F/RAND range.

Justice Briss has held in Unwired Planet v. Huawei that the ND prong does not present a hard-edged non-discrimination obligation, ${ }^{331}$ but requires SEP holders to establish a benchmark royalty rate that is applicable to all licensees seeking the same kind of a license. ${ }^{332}$ The emphasis is on the nature of the transaction. It has been argued that the nature of the transactions between the SEP holder and the licensees may change the extent of similarity of the licensees' situations. ${ }^{333}$ Justice Briss specified further that royalties must not be based on the size, bargaining power, or other characteristics of the licensee. ${ }^{334}$ In TCL $v$. Ericsson, Judge Selna considered some relevant factors in determining whether licensees are similarly situated to be the geographic scope of the licensee's business, the required license, and sales volume, in addition to the nature of manufactured devices in which the standard is implemented. ${ }^{335}$ For example, licensees whose sales occur mostly in one single country and who need a license in only one jurisdiction may not be similarly situated to licensees conducting business in various countries or geographic markets and needing a global license. ${ }^{336}$ Moreover, Judge Selna rejected factors such as the licensee's overall financial success or risk, brand recognition, device operating system, or retail stores. ${ }^{337}$ He held that F/RAND royalty rates may vary depending on the 'economics of the specific license. ${ }^{338}$

F/RAND license terms may legitimately vary even across similarly situated licensees according to different licensing arrangements. There is a wide variety of licensing arrangements as license terms cover many different issues. Differences may appear for instance in the type of remuneration. Commentators such as Sidak, Carlton, Shampine, and Richard J. Gilbert have advocated an idea that F/RAND-committed

\footnotetext{
329 ibid at 74 .

330 Microsoft v Motorola, (WD Wash Apr 25, 2013), at 5; Contreras, 'Global Markets, Competition, and FRAND Royalties: The Many Implications of Unwired Planet v Huawei' (n 61) 4; Pentheroudakis and Baron (n 32) 13.

331 Unwired Planet v Huawei [2017] EWHC 711, para 501.

332 ibid para 503.

333 Sidak, 'Fair and Unfair Discrimination in Royalties for Standard-Essential Patents Encumbered by a FRAND or RAND Commitment' (n 59) 361.

334 Unwired Planet v Huawei [2017] EWHC 711, paras 175, 806(8).

335 TCL $v$ Ericsson, (CD Cal Dec 21, 2017), at 58.

336 ibid at 59.

337 ibid at 58 .

338 ibid at 109 .
} 
SEP holders are obliged to offer licensees the same menu of license terms, ${ }^{339}$ with remuneration possibilities ranging between a fixed fee, a per-unit running royalty, a royalty declining with output, etc. ${ }^{340}$ Furthermore, arrangements like cross-licensing may function as payment in kind. ${ }^{341}$

An open question remains whether a F/RAND-committed SEP holder is legally allowed to set differential royalties to new licensees under exceptional circumstances such as changed market conditions and the need to meet competition from an alternative technology when the value of the SEP has changed. Such circumstances provide a justification for differential pricing under Section 2(a) of the RobinsonPatman Act. ${ }^{342}$ Commentators have shed light on the issue. ${ }^{343}$ For instance, Contreras and Layne-Farrar have remarked that a previously charged royalty rate may no longer be reasonable later when the market and technology have progressed. ${ }^{344}$ They have argued that the concept of F/RAND should be adaptable to changing market conditions. ${ }^{345}$ Nevertheless, signed F/RAND license agreements with specified durations should be considered binding and inalterable in the passage of time for the sake of contractual and business certainty. ${ }^{346}$

It is important to keep in mind that charging discriminatory royalties may also amount to an antitrust violation in both U.S. and EU law if the SEP holder is considered to have sufficient market power and its conduct is capable of resulting in primary line or secondary line injury to competition. EU law is generally stricter with regard to use of market power than U.S. law: whereas U.S. law is concerned about monopolization in Section 2 of the Sherman Act, EU law is cautious about abusive use of mere dominance in Article 102 of the TFEU. EU law is focused on the structure of the market and it is very suspicious of concentration of power. ${ }^{347}$ Patent related conduct is subject to antitrust scrutiny even when it falls within the scope of the patent, ${ }^{348}$ especially in EU law. EU law allows interference into a patentee's right to exclude more easily than U.S. law - a dominant company may even be imposed a duty to license its patented technology as dominant undertakings are under a special responsibility to allow effective competition. ${ }^{349}$ Price discrimination is expressly prohibited under Article 102(c) of the TFEU in EU law, and in U.S. law under Section 2(a) of the Robinson-Patman Act with regard to tangible commodities, although it has been ignored by the U.S. antitrust agencies. ${ }^{350}$ Also in the context of standard setting

\footnotetext{
${ }^{339}$ Gilbert (n 16) 875; Carlton and Shampine (n 40) 546; Sidak, 'The Meaning of FRAND, Part I: Royalties' (n 28) 999.

340 Gilbert (n 16) 875; Sidak, 'The Meaning of FRAND, Part I: Royalties' (n 28) 998.

${ }^{341}$ Gilbert (n 16) 875; Layne-Farrar (n 53) 833; Sidak, 'Fair and Unfair Discrimination in Royalties for Standard-Essential Patents Encumbered by a FRAND or RAND Commitment' (n 59) 356-357.

342 See, for instance, Texas Gulf Sulphur v JR Simplot (9th Cir 1969), at*806-07.

343 Carlton and Shampine (n 40) 551; Contreras and Layne-Farrar (n 188) 205-206; Sidak, 'Fair and Unfair Discrimination in Royalties for Standard-Essential Patents Encumbered by a FRAND or RAND Commitment' (n 59) 368.

${ }^{344}$ Contreras and Layne-Farrar (n 188) 205-206.

345 ibid 206.

346 ibid.

347 Cases C-501/06 P GlaxoSmithKline Services [2009], para 63.

348 FTC v Actavis, 133 S Ct 2223 (2013); Case T-201/04 Microsoft [2007].

349 Case T-201/04 Microsoft [2007].

${ }^{350}$ Layne-Farrar and Stuart (n 17) 58.
} 

and F/RAND licensing, the threshold for antitrust liability is significantly lower in EU law. In EU law, the SEP holder's conduct must be merely proved to be abusive use of the market power conferred by the essentiality of the standard, whereas in U.S. law the SEP holder must also have made a fraudulent promise to the SSO to license its patented technology on F/RAND terms. ${ }^{351}$ Nevertheless, charging discriminatory royalties might enhance consumer welfare and the potential efficiencies might justify the anti-competitive conduct. ${ }^{352}$

\section{CONCLUSION}

The ND prong of F/RAND commitments imposed on SEP holders has become a subject of debate and litigation. Those commitments have been enforced through contract law and antitrust law. There is no agreement on the practical implications of the ND prong, and it has been uncertain whether a F/RAND-committed SEP holder is legally allowed to charge differential royalties to licensees for the use of the patented technology and to what extent. According to the dominant perception, SEP holders are obliged to license to similarly situated licensees on similar license terms. Yet, the concepts of similarly situated and similar terms are open-ended. The purpose of this paper has been to resolve this ambiguity of the ND prong by examining SSOs' bylaws, inspecting U.S. and EU antitrust norms, analyzing case law of the U.S. and European courts, and reviewing legal and economic arguments in the academic literature.

This paper has sought to provide a practical framework for answering the question: 'To what extent is a F/RAND-committed SEP holder legally allowed to charge differential royalties to different licensees for the patented technology from the U.S. and the EU perspectives?' After discussing the patent regime generally and limitations on SEP holders' freedom to license aiming to prevent abuse of market power, the profound analysis of the ND prong begun with examining IEEE, JEDEC, and ETSI's policies as F/RAND commitments are essentially agreements between patentees and SSOs. It is clear from the SSOs' bylaws that the objective of the ND prong is to ensure that SEPs are available to all implementers, and that SEP holders are allowed to set differential license terms to different licensees. Based on the interpretations provided in the case law and academic literature, licensees manufacturing dissimilar devices are not similarly situated, and hence a F/RANDcommitted SEP holder is legally allowed to charge differential royalties at least to those licensees provided that the value contributed by the patented technology to the particular devices is apportioned convincingly. Licensees manufacturing similar devices are not inevitably similarly situated either, as factors relating the nature of the transactions, such as the scope of the licenses, may change the degree of similarity of the licensees' situations. Furthermore, it appears that F/RAND royalties may legitimately vary even across similarly situated licensees according to different licensing arrangements so long as the same menu of terms is available for all licensees.

\footnotetext{
351 Broadcom v Qualcomm, (3d Cir 2007), at 315.

352 United States v Microsoft, (DC Cir 2001), at 59; C-209/10, Post Danmark A/S v Konkurrencerädet, EU:C:2012:172, paras 40-42.
} 
Discrimination in royalties for the use of patented technology essential to implementation of a standard may constitute not only a breach of contract but also an antitrust violation in both U.S. and EU law when the company is considered to have sufficient market power and its conduct is considered anti-competitive. However, EU competition law is generally more suspicious with regard to use of market power than U.S. antitrust law, and EU law allows interference into a patentee's right to exclude more easily. Also in the context of standard setting and F/RAND licensing, the threshold for antitrust liability is clearly lower in EU law. In U.S. antitrust law, a SEP holder's conduct may trigger liability only if the SEP holder has made a fraudulent promise to the SSO to license its patented technology on F/RAND terms. This specific condition is not found in EU law.

The ambiguity of the ND prong has given rise to legal uncertainty and inefficiency in standard setting. The courts of the U.S. and Europe have not provided any definitive all-encompassing answers. However, based on recently emerged ideas, it is certain that F/RAND-committed SEP holders are given some leeway to negotiate and set license terms. They may charge differential royalties to different licensees lawfully to some extent, even to similarly situated licensees. Nonetheless, SEP holders might want to keep a close eye on the still evolving law and the differences between jurisdictions. 